\title{
Review Article: Atmospheric conditions inducing extreme precipitation over the eastern and western Mediterranean
}

\author{
U. Dayan $^{1}$, K. Nissen ${ }^{2}$, and U. Ulbrich ${ }^{2}$ \\ ${ }^{1}$ Department of Geography, Hebrew University of Jerusalem, Jerusalem, Israel \\ ${ }^{2}$ Institute of Meteorology, Free University of Berlin, Berlin, Germany \\ Correspondence to: U. Dayan (msudayan@mscc.huji.ac.il)
}

Received: 22 February 2015 - Published in Nat. Hazards Earth Syst. Sci. Discuss.: 10 June 2015

Revised: 2 November 2015 - Accepted: 8 November 2015 - Published: 20 November 2015

\begin{abstract}
This review discusses published studies of heavy rainfall events over the Mediterranean Basin, combining them in a more general picture of the dynamic and thermodynamic factors and processes that produce heavy rain storms. It distinguishes the western and eastern Mediterranean in order to point out specific regional peculiarities. The crucial moisture for developing intensive convection over these regions can be originated not only from the adjacent Mediterranean Sea but also from distant upwind sources. Transport from remote sources is usually in the mid-tropospheric layers and associated with specific features and patterns of the larger-scale circulations. The synoptic systems (tropical and extratropical) that account for most of the major extreme precipitation events and the coupling of circulation and extreme rainfall patterns are presented. Heavy rainfall over the Mediterranean Basin is caused at times in concert by several atmospheric processes working at different atmospheric scales, such as local convection, upper synoptic-scale-level troughs, and mesoscale convective systems. Under tropical air-mass intrusions, convection generated by static instability seems to play a more important role than synoptic-scale vertical motions. Locally, the occurrence of torrential rains and their intensity is dependent on factors such as temperature profiles and implied instability, atmospheric moisture, and lower-level convergence.
\end{abstract}

\section{Introduction}

Extreme precipitation events can lead to flooding and pose a threat to human lives and infrastructure. The intensity of precipitation events depends on the location and depth of the cyclones that induce precipitation and the characteristics of their environment, such as orography, sea-surface temperature and availability of moisture. However, these are not the sole conditions favoring the generation of heavy precipitation. The atmospheric conditions at several spatial and temporal scales (i.e., large-scale circulation and regional to local thermodynamic conditions) play an important role in shaping the outcome of such extreme rain events and their associated severe consequences. In this review, we abstained from adopting a single definition of extreme rainfall intensity for the whole Mediterranean region (MR), since high rainfall events, depending on their frequency, duration and timing, lead to different thresholds and return periods which differ throughout the several regions analyzed.

Several atmospheric factors can contribute to the development and occurrence of heavy rainfall over the MR, such as mesoscale convective systems (Dayan et al., 2001; Delrieu et al., 2005), cyclones (Alpert et al., 1990a; Homar and Stensrud, 2004), upper-level troughs (Kotroni et al., 2006; Knippertz, 2007) and large-scale circulation teleconnection patterns (Xoplaki et al., 2004; Krichak and Alpert, 2005; Feldstein and Dayan, 2008). However two essential components are required to generate extreme precipitation. The water vapor content of the atmosphere must be high and the onset of rain must be triggered by a thermodynamic or dynamic process. This moisture content is critical in knowing if conditional instability contains the potential for an air parcel to become buoyant. The main origin of buoyant instability is both latent and sensible heat produced at low atmospheric levels caused by solar heating and evaporation. Intense convection can then produce an intense precipitation event (Massacand et al., 1998). 

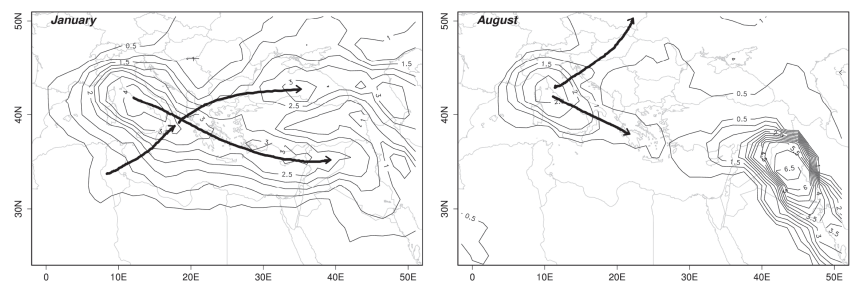

Figure 1. Isolines: average number of tracks passing within a radius of $250 \mathrm{~km}$ from the center of each cell counted on a $1.5 \times 1.5$ grid in the ERA Interim data set (i.e., cyclone track density). Arrows (taken from Alpert et al., 1990b) show the main tracks of migrating lows over the MB during winter (January) and summer (August).

Convective storms that induce heavy rain necessitate, beside sufficient moisture and conditional instability, a lifting mechanism in order to initiate convection. Apparently, the large-scale ascent of synoptic systems (of a few centimeters per second) is too weak to trigger such processes, implying that such a trigger is generally a product of mesoscale processes. However, in an attempt to explain the interlacing relationship between the large-scale- and mesoscale-derived processes, Doswell III (1987) proposed a framework for understanding their interaction. He suggests regarding large-scale systems as pure "quasi-geostrophic"; they are predominant in mid-latitudes and as such are subject to vorticity advection and thermal advection which drive the flow out of the thermal wind balance that induces vertical motion. These largescale advection processes supply sufficient thermodynamic support, permitting strong convection. In general, when the mesoscale initiation process operates in a large-scale environment favorable to deep and moist convection, the result is most likely to be widespread intense thunderstorms associated with heavy rain.

In this study we review the scientific literature dealing with the conditions that can lead to extreme precipitation events in the eastern and western Mediterranean (EM; WM) regions. Following the description of the climatological background of the region (Sect. 2), the moisture sources for developing intensive convection over the basin are specified (Sect. 3). Next, the interaction between the tropics and extratropics manifested by several atmospheric processes is discussed (Sect. 4). This discussion is followed by a description of the mechanisms that govern the rainfall variability (Sect. 5). The next two sections review the scientific literature that deals with the spatial distribution of deep convective precipitation over the MR resulting from the synoptic patterns that induce rain over both parts of this region (Sects. 6 and 7). Next, we identify the dynamic and thermodynamic factors in the upper level and at the surface that are involved in producing heavy rain storms over the study region (Sect. 8). In Sect. 9 the main findings and conclusions are summarized.

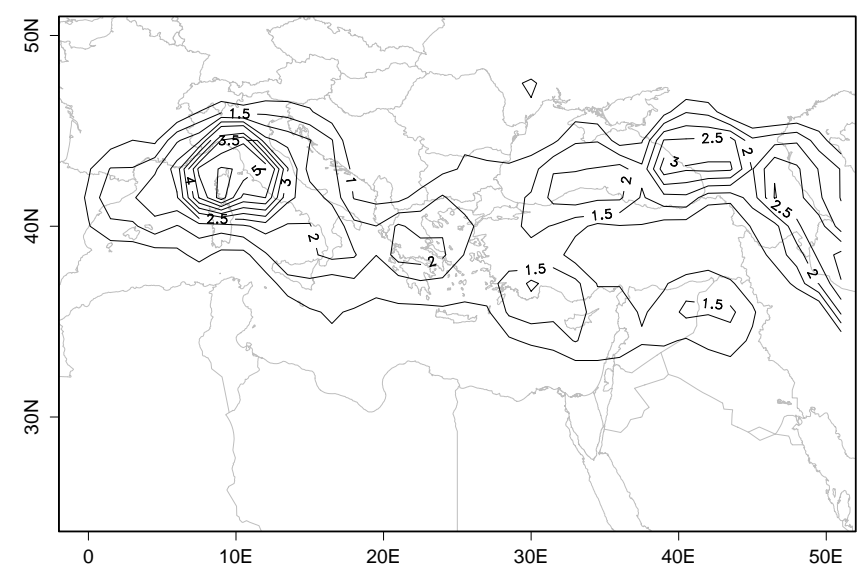

Figure 2. Cyclogenetic regions over the MB in winter (DJF) determined using the ERA Interim reanalysis data set for the period 1979-2012. Contour interval 0.5 cyclone/winter; first contour is 1.0 .

\section{Mediterranean climatic conditions and cyclogenesis}

There are substantial regional differences in rain rates over the MR. The maximum rainfall rate $\left(3-5 \mathrm{~mm} \mathrm{day}^{-1}\right)$ occurs over the mountainous regions of Europe, while the minimum rainfall rate is over the central and eastern coasts of north Africa $\left(\sim 0.5 \mathrm{~mm} \mathrm{day}^{-1}\right)$. An average rain rate of $\sim 1-$ $2 \mathrm{~mm} \mathrm{day}^{-1}$ is observed over the whole region with a maximum over its western part (Alpert et al., 2002; Raveh-Rubin and Wernli, 2015). The climate over the MR, defined by Koeppen as "Interior Mediterranean" (Csa classification), is temperate, with winter rain over most areas. During the summer, the subtropical high drifts northward and eastward, covering the whole African coast. During this season, sinking air produces a strong upper level subsiding inversion (Dayan and Rodnizki, 1999; Dayan et al., 2002). In winter the subtropical high pressure cell moves south, enhancing the probability of a penetration of rain-producing mid-latitude synoptic systems as well as the development of extratropical cyclones in the Mediterranean Basin (MB).

The main tracks of lows migrating into the Mediterranean in winter are found over the northern part of this basin (Fig. 1). Penetrating cyclones may deepen over the warm Mediterranean waters, while cyclones that form are focused around four cyclogenetic centers, with a dominating region in the Gulf of Genoa, and secondary centers in south Italy, Crete, and Cyprus (Fig. 2). The latter center is characterized by a stronger baroclinic character as compared to other MB cyclogenetic centers (Maheras et al., 2002). Mediterranean lows are less intensive and of shorter life cycles than Atlantic synoptic systems (Trigo et al., 1999; Hoskin and Hodges, 2002; Raible, 2007). Raible (2007) analyzed the connection of extremes' mid-latitude cyclone intensity with atmospheric circulation patterns, utilizing the ERA40 data set from 19582001. Cyclone intensity was determined by an index defined as the $90 \%$ percentile of $1000 \mathrm{hPa}$ geopotential height gradi- 

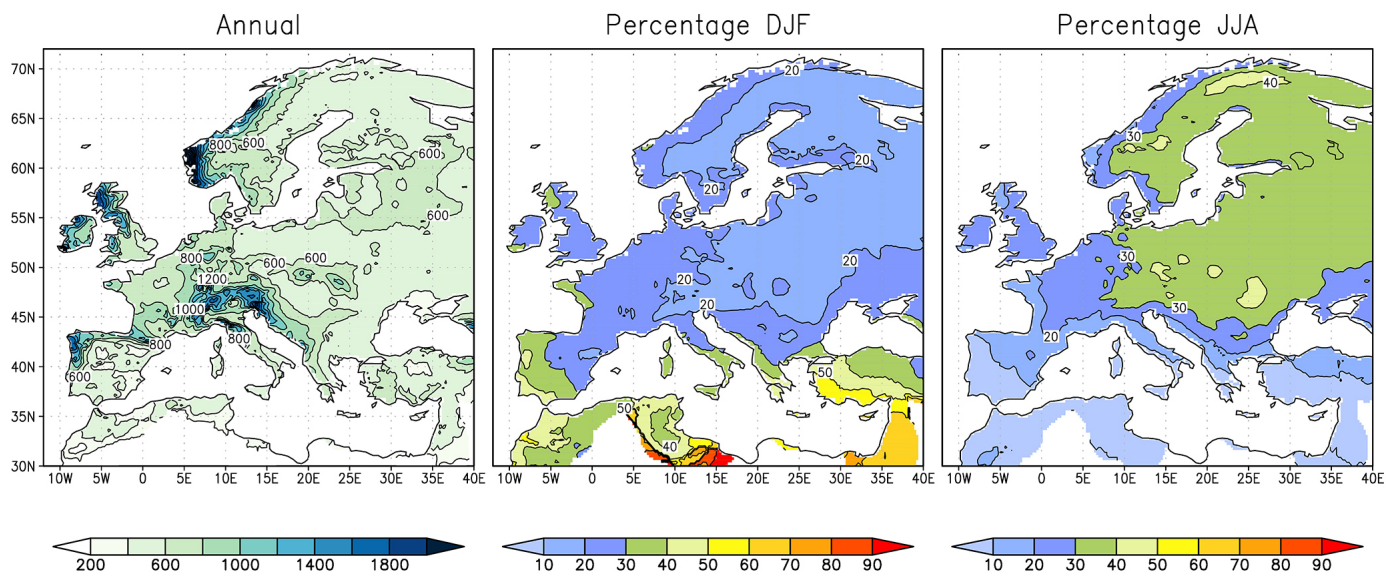

Figure 3. Precipitation in Europe and the Mediterranean region computed from the E-OBS data set (Haylock et al., 2008). Panel (a) shows annual mean rainfall, contour interval $200 \mathrm{~mm}$. Panels (b) and (c) show the percentage of the annual precipitation that falls in winter (December, January, and February), and in summer (June, July, and August), respectively. Contour interval $10 \%$.

ent around a cyclone center per $1000 \mathrm{~km}$. His results indicate that over southern Europe and the MB, extremes in cyclone intensity remained constant during this period. Moreover, he found that extreme intensified mid-latitude cyclones over the $\mathrm{MB}$ are related to the large-scale atmospheric circulation in winter; however such connections are not developed in summer, suggesting that in summer other processes, e.g., convection, play an important role in generating extremes in precipitation.

Penetrating frontal lows are the main cause for a significant amount of summer rainfall over the northwestern part of the MR, amounting about a quarter of the yearly sum (Romero et al., 1998). Over the east and southeast MR, summer cyclonic activity vanishes due to the predominance of the subtropical high aloft, leading to subsidence. Consequently, all regions featured by a Mediterranean climate regime - eastern Spain, the south of France, south and central Italy, Greece, southern Turkey, Syria, Lebanon, and Israel - are characterized by summer dryness (Raveh-Rubin and Wernli, 2015) (Fig. 3). Northern Italy and the northern Adriatic feature maximum rain amounts during fall, caused by an air-mass destabilization over the warmer sea surface temperature (Ventura et al., 2002). Maximum rain amounts during spring are typical for the internal continental regions such as the Anatolian Plateau (Turkey), and central Spain. They are caused by strong free-convection conditions in these regions.

A contributing factor to the Mediterranean cyclogenesis is the relatively high level of sea surface temperatures (SST) as compared to the colder layer of air above it during fall and winter, which increases the instability of shallow atmospheric layers that enhance the generation of lows over the sea (Marullo, et al., 1999; Flocas et al., 2010). The satellite SST data show that during the winter, the SST is warmer and more homogeneously distributed than the ground temperature, spanning from $\sim 12$ to $18^{\circ} \mathrm{C}$ ) (Fig. 4 ).
Another important contributing factor that characterizes the MR is lee cyclogenesis, a phenomenon that has attracted theoreticians for a long time. One of the first studies that deals with mountain lee cyclogenesis was conducted by Speranza (1975) who stated the following: "the fact that cyclones occur more frequently over the Gulf of Genoa than in surrounding regions suggests that cyclogenesis must be induced by the influence of the ground". The general picture that emerges from this pioneering and comprehensive study is the fact that the interaction of large-scale atmospheric flows with the Alpine barrier produces secondary flows of different horizontal extent, intensity, and duration. Ten years later, Speranza et al. (1985) proposed a theory of Alpine cyclogenesis, pointing out the fact that this phenomenon occurs as a result of the interaction of a preexisting baroclinic disturbance with the Alps. Further, they found that the intensity of baroclinic waves to the bottom topography is substantial for the sustainment of deep Alpine cyclogenesis that induces heavy rain.

The Atlas Mountains over the southwestern part of the MB are also prone to mountain cyclogenesis which leads to the initiation of deep Mediterranean cyclones over the WM. Egger et al. (1995) used a three-level channel flow model to investigate the generation of "Sharav depressions" which referred to Sharav cyclones in the lee of the Atlas Mountains. This type of cyclone is a thermal low, which is enhanced by vigorous boundary-level baroclinicity caused by the steep thermal gradient existing between the heated land and the cold Mediterranean Sea (Alpert and Ziv, 1989). Their idealized experiments demonstrate that lee cyclones can be formed if a cold-air outbreak occurring in the rear of a low is blocked by the mountain.

Another essential factor is the associated strong potential vorticity anomaly, featuring the axis of the accompanying upper-level trough in its southward excursion while crossing 


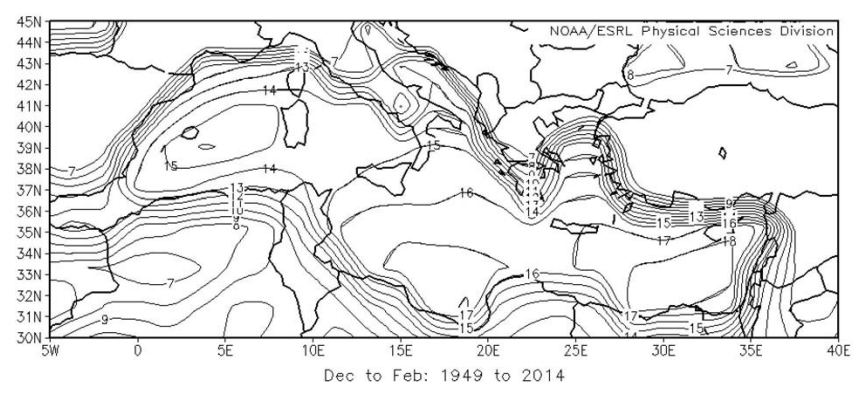

Figure 4. Long-term mean skin temperature over the MB for winter (December-February) 1949-2014. Skin temperature includes both land surface temperature (LST) and SST. SST is derived from the NOAA operational global sea surface temperature by analyzing 7 days of in situ (ship and buoy) and satellite SST data taken from SST data in Reynolds (1994). LST is calculated according to an analytic model (Pan and Mahrt 1987). (Both are integrated in NCEP/NCAR Reanalysis model: http://www.esrl.noaa.gov/psd/ cgi-bin/data/composites/plot20thc.v2.pl).

the mountain range. Under such circumstances, the upperlevel trough intensifies and induces the formation of a lowlevel cyclone in the lee. Numerical simulations using the MM5 forecast model by Horvath et al. (2006) have shown that orography-blocking is responsible for the generation of a low-level shallow vortex in the first phase of the lee development. Further, their results have indicated that upper-level dynamical factors were found to be responsible for the advection of such systems to the MB, while orography tends to keep the cyclone stationary or to delay its migration to the basin.

\section{Moisture sources}

Air moisture advection from outside of the MB associated with heavy precipitation events has been addressed in numerous studies (e.g., Sodemann and Zubler, 2010; Duffourg and Ducrocq, 2011; Reale and Lionello, 2013; Krichak et al., 2015). Even though north Atlantic moisture sources may be important in controlling the interannual variability of heavy precipitation events (Drumond et al., 2011) in the MB, the moisture generated within this basin is the major moisture supply associated with winter Mediterranean cyclones, especially whenever long fetch of regional winds, e.g., Sirocco, are associated with abundant moisture (De Zolt et al., 2006; Winschall et al., 2014).

Over the EM, however, this source is less effective as a moisture supplier during the transitional seasons featured in southeasterly flows at low tropospheric layers. Levy et al. (2008) have indicated that such easterlies amounted to nearly $40 \%$ of the total surface flow in winter. Earlier studies by Dayan and Sharon (1980), Krichak et al. (1997), and Saaroni et al. (1998) have shown, for example, that the area over the Red Sea quite often serves as a corridor for trans- porting air masses from the Arabian Sea and tropical Africa into the southeastern Mediterranean. The air coming from the south, still warm, absorbs large quantities of water vapor while crossing the northern part of the Red Sea up to the EM. The crucial moisture for the developing convection in such a situation is often confined to the mid-tropospheric layers.

Moisture from remote origins, such as the intertropical convergence zone (ITCZ) plays an additional role, as shown for a specific rainstorm event by Krichak and Alpert (1998). Both observations and numerical experiments confirmed a major moisture source associated with intensified tropical convection over eastern Africa. Evidence was given that both moisture sources were not independent. The enhanced convection contributed to the intensification of the subtropical jet (STJ) over the Red Sea, which in turn triggered the development of the low-level trough.

Independent of the Red Sea source, moisture from the African part of the ITCZ played a role in a spring rainstorm (March 1985) over the EM region. Zangvil and Isakson (1995) found that the moisture originated from tropical Africa and that the maximum transport took place in the 850 $700 \mathrm{hPa}$ layer. Dayan et al. (2001), using satellite water vapor imagery, showed that moisture originating from western tropical Africa was transported within the mid-troposphere to the southern Levant during a severe fall storm (October 1997) that skimmed the southern parts of the EM and stimulated intense convection under conditional instability associated with synoptic-scale forcing. Ziv (2001), in an analysis of a rainstorm over Egypt and southeastern Israel associated with a tropical plume, also found that the moisture originated from western equatorial Africa. It was transported eastward at the mid-levels above the dry planetary boundary layer of Sahara to the EM.

For the western parts of the MR, the role of remote moisture sources for extreme rainfall events has been demonstrated by Knippertz and Martin (2005), for example. They discuss a case of extreme precipitation in the Atlas Mountains associated with a plume of moisture from low latitudes advected along the west African coastline. Even for events in the central Mediterranean, a significant role of moisture import into the basin was detected. Pinto et al. (2013) found that moisture advection from the north Atlantic plays a relevant role in the magnitude of the extraordinary rainfall events over northwest Italy, while humidity transports from the north Atlantic are less important for weaker events in the same region.

These results show that a significant, if not a major part of moisture necessary for developing intensive convection over the MR can be originated from distant upwind sources and transported at elevated tropospheric layers. As found by Knippertz and Wernli (2010; their Fig. 1), there is a maximum of tropospheric poleward moisture transport in the vicinity of the Atlas Mountains, though it is weaker than the respective meridional moisture transports in other regions of the world. They also show that outbreaks of tropical moisture over the western and central Atlantic can affect the Mediter- 
ranean as the track may turn eastward in conjunction with the STJ (Knippertz and Martin, 2005), thus making the tropical Atlantic a relevant moisture source (Duffourg and Ducrocq, 2011; Raveh-Rubin and Wernli, 2015). The important role of the Atlantic Ocean in serving as a major source was addressed also by Mariotti et al. (2002a). They calculated the vertically integrated atmospheric water vapor flux over the whole basin, based on NCEP and ERA reanalyses and found that the major moisture flux source is the Atlantic Ocean. They noted that this flux is much stronger over the sea than the surrounding land regions and is subject to a southeastward direction in the summer over the eastern part of the basin, probably driven by the prominent Etesian winds over this region.

Drumond et al. (2011) analyzed the variation in moisture sources related to drier and wetter conditions in regions around the MB using the three-dimensional Lagrangian FLEXPART model for backward trajectories. They conducted a seasonal analysis, identifying years with the lowest/highest rates of precipitation averaged over eight different continental regions (Iberian Peninsula, France, Italian Peninsula, Balkan Peninsula, eastern and western Mediterranean, central and east north Africa). The results show that the Iberian Peninsula is mostly influenced by moisture from the Mediterranean and Atlantic (western European coast to the subtropical-tropical north Atlantic - STNA). France is influenced by moisture from western Europe and the STNA. The Italian and Balkan peninsulas are affected by moisture originating in the MB. In a similar study, Gomez-Hernandez et al. (2013) pointed out the west Mediterranean Sea as the dominant moisture source for most $\mathrm{MB}$ regions during the wet season.

\section{Tropical extratropical interactions}

Interactions between the tropics and extratropics is manifested by several atmospheric processes, such as deep upperlevel troughs penetrating into the tropics or Rossby waves connecting mid-latitudes and low latitudes. Sometimes, during transitional seasons, especially in fall, global systems deviate from long-term seasonal climatology and the EM, being on the edge of subtropical and mid-latitude climate, can be affected by the interaction of tropical and extratropical systems (Dayan et al., 2001). A typical phenomenon manifesting the transport of tropical moisture to the extratropics is the "tropical plume" (TP). These plumes refer to elongated cloud bands at middle and upper atmospheric levels extending from the tropics into subtropics. Kuhnel (1989) classified cloud bands crossing Africa into two separate bands: the Saharan (i.e., west African) and the east African band, both with frequency maxima in winter. The Saharan cloud band, about 3 times more frequent than the east African band, occurs between October and March, whereas the latter is most frequent between February and May. The typical struc-

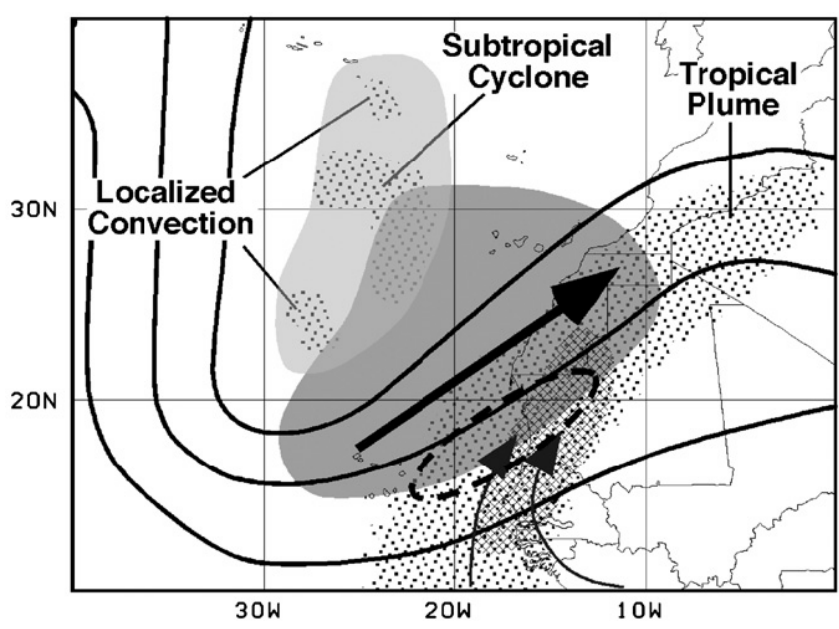

Figure 5. Schematic depiction of the synoptic situation during precipitation events over west Africa in connection with tropical plumes. Thick black lines delineate the low-latitude upper trough and the thick arrow indicates the associated subtropical jet streak. Thin arrows show mid-level moisture transports from the deep tropics. Stippled regions indicate high clouds, and hatching delineates the major precipitation zone. Light (dark) gray shading depicts the region of convective instability under the coldest air at upper levels (positive quasi-geostrophic forcing for mid-level ascent). The dashed lines bound a region of upper-level inertial instability along the anticyclonic shear-side of the jet (from Knippertz (2007), reprinted with permission of Elsevier).

tural characteristics of west African TPs were summarized by Knippertz (2007) and are displayed in Fig. 5.

TPs typically exhibit a poleward and eastward orientation with an anticyclonic curvature in the subtropics. Most TPs originate from an active segment of the ITCZ and are located at the eastern side of an upper-level trough, which penetrates into the tropics. The east African band, affecting mainly the eastern MR, was not studied in depth. Observations of the rainfall associated with the tropical cloud development related to such jet streams extending from the tropics into the subtropics, analyzed by Tubi and Dayan (2014) as well as in previous studies in this region (e.g., Dayan and Abramski 1983; Ziv, 2001; Rubin et al., 2007), indicate that their contribution to the water budget in the Middle East, particularly in arid and semiarid locations, is important. Dayan and Abramski (1983) described a major and fatal flooding event caused by very heavy showers that yielded a daily rain amount of $52 \mathrm{~mm}$ (a value equivalent to $160 \%$ of the annual average) in Eilat, at the southern tip of Israel, as part of the torrential rain event that occurred over most of the southeastern parts of the MR. The involved TP originating from western Africa was attributed to a pronounced disturbance in the STJ over northeastern Africa. Ziv (2001) examined a rainstorm that resulted in a total rainfall rate of over $40 \mathrm{~mm}$ recorded over northern Israel within about $24 \mathrm{~h}$. This storm was associated with a TP over eastern Africa and the Middle East 

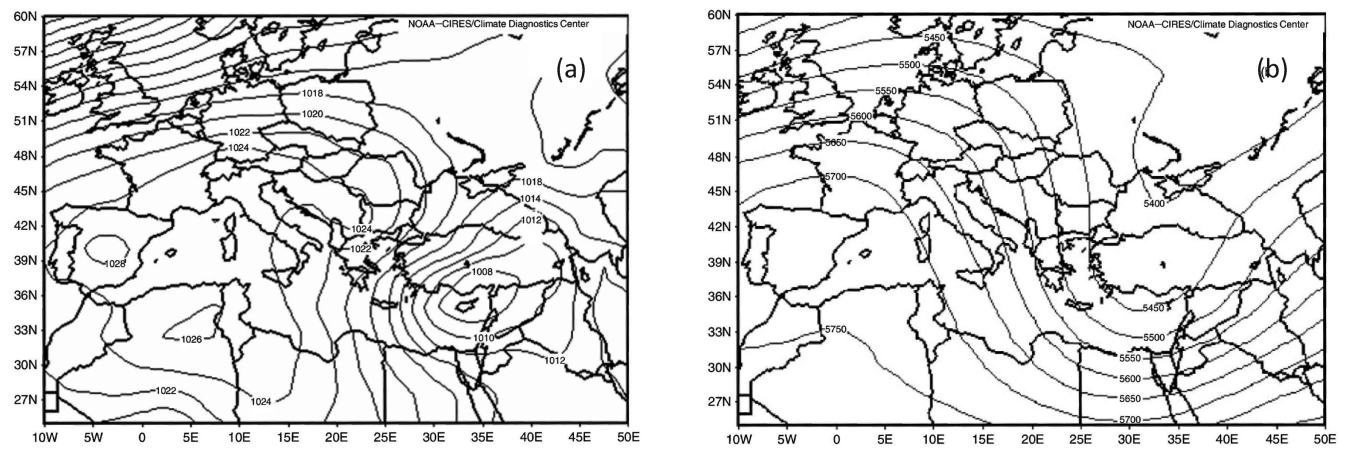

Figure 6. Composite maps for the 10 heaviest rainfall days in Israel for the period 1950-2002. Left figure: SLP (hPa); right figure: $500 \mathrm{hPa}$ gph (m) (from Ziv et al. (2006), reprinted with permission of John Wiley and Sons).

and pointed out wind flow acceleration at the jet entrance contributing to tropical convection and near-tropospheric divergence in the inflection point ahead of the accompanying subtropical upper-level trough.

The main canonical characteristics of rain-producing TPs over eastern north Africa were identified by Rubin et al. (2007) while investigating 10 selected plumes between 1988 and 2005. One of these plumes affected the EM in 22 March 1991 during which considerable rainfall was observed over the entire region, with a maximum of $80 \mathrm{~mm}$ near Jerusalem, Israel. They have shown that the moisture supply for the rain production is composed of horizontal moisture convergence near the TP origin and a fast and effective mobilization along the plume toward the target area (i.e., the EM). Their analysis has put the efficiency of TPs in the longrange transport of mid-level moisture and their role as rain contributors over desert regions in context.

In their recent study, Tubi and Dayan (2014) identified a new TP cluster originating in central to eastern Africa, referring to "southern" plumes of a shorter fetch. In this TP category, the STJ is accompanied by an anticyclonic flow over the south of the Arabian Peninsula, which serves as an essential vehicle transporting moisture from central to east African sources. An objective climatology of tropical plumes (Fröhlich et al., 2013, their Fig. 7) suggests that in particular the number of Atlantic plumes greatly exceeds those occurring south of the MB. They can also affect the MR when moisture advection turns eastward in conjunction with the subtropical jet (e.g., Knippertz and Wernli, 2010). It should be noted that relevant moisture outbreaks from the low latitudes and the occurrence of extreme rainfall events over the MR have also been observed in conjunction with Atlantic hurricanes (Reale et al., 2001; Turato et al., 2004).

Lavers and Villarini (2013) have shown that TPs, which they refer to as "atmospheric rivers" (AR), do cause extreme rainfall over the WM particularly in fall and winter. Based on a latitude-dependent integrated vapor transport threshold calculated between 1000 and $300 \mathrm{hPa}$, and daily observed gauge-based precipitation for 1979-2011, they fur- ther showed that about $10 \%$ of the annual maximum daily precipitation events in fall and winter are related to ARs.

\section{Mechanisms governing total and extreme rainfall variability}

In the EM, the synoptic-scale system responsible for about $90 \%$ of the annual rainfall is an extratropical cyclone - the Cyprus Low (Goldreich, 2003). The surface low over the EM featuring the heaviest rainfall days is generally accompanied by high pressure over the WM (Fig. 6a). The concurrent upper-level system (Fig. 6b) consists of a pronounced trough extending toward southwestern Turkey as shown in the composite maps of SLP and $500 \mathrm{hPa}$ gph for the 10 heaviest rainfall days in Israel for a period of 52 years starting from 1950 (Ziv et al., 2006). Furthermore, the analysis performed by Ziv et al. (2006) based on rainfall time series for December, January, and February for the period of 1950-2002 over the EM revealed that an upper level trough extending from east Europe toward the EM is closely linked with the seasonal rainfall over this part of the MR, as expressed by a correlation of -0.74 between the $500 \mathrm{hPa}$ gph at $32.5^{\circ} \mathrm{N}, 35^{\circ} \mathrm{E}$ and the rainfall.

In a regional context, wet rainfall conditions were found to be characterized by negative pressure departures and westerly circulation over the EM. Moreover, in many cases dry conditions over the EM were associated with below-normal pressure conditions over central or western Europe, while wet conditions with above-normal conditions over the same region, thus reflecting the so-called Mediterranean Oscillation (MO) (Conté et al., 1989; Kutiel and Paz, 1998; Törnros, 2013). Aiming to determine the Eurasian pressure patterns which are associated with dry or wet conditions over the EM, Krichak et al. (2000) found that during dry spells positive SLP and $500 \mathrm{hPa}$ gph anomaly patterns prevail over eastern Europe, while negative SLP and $500 \mathrm{hPa}$ gph anomalies are found over southwestern and western Europe.

Few modes of variability play a role in the total rainfall in the MR. Associations between the Pacific El Niño/Southern 
Oscillation (ENSO) and Mediterranean precipitation have been described by several researchers (e.g., Ropelewski and Halpert 1987; Rodo et al., 1997; Price et al., 1998; Mariotti et al., 2002b). Over the WM, several studies have demonstrated statistical associations between Iberian region precipitation and ENSO (Rodo et al., 1997; Mariotti et al., 2002b; Park, 2004; Rimbu et al., 2001; Pozo-Vazquez et al., 2005; Vicente-Serrano, 2005; Sordo et al., 2008). Shaman and Tziperman (2011), based on observational analyses, show that ENSO modulates rainfall over southwestern Europe (Iberia, southern France, and Italy) during the SeptemberDecember wet season. These precipitation anomalies are associated with changes in large-scale atmospheric rields to the west of Iberia that alter low-level westerly winds and onshore moisture advection from the Atlantic. Alpert et al. (2002) found that torrential rainfall categories $\left(>64 \mathrm{~mm} \mathrm{~d}^{-1}\right)$ tend to peak in El Niño years mainly over central Mediterranean (Italy) for the El Niño years 1953, 1965, 1982/1983, and $1986 / 1987$. However, the influence over the EM is seasonally dependent, small, and intermittent (Ziv et al., 2006).

In order to assess the global circulation anomalies with which the WM total rainfall is associated, Mariotti et al. (2002b) analyzed the interannual variations of rainfall over this part of the basin in relation to major ENSO events based on SST anomalies. They found a positive correlation between CRU rainfall, NCEP rainfall, and NCEP moisture flux, extending from the subtropical Atlantic Ocean into the MR (Fig. 7). The anomalous atmospheric circulation associated with this moisture advection as obtained for a particular stage of the ENSO cycle plays a relevant role in the magnitude of the rainfall events in fall (Pinto et al., 2013).

Another index which affects the total rainfall variability significantly, not only in Europe, but also over the western and central parts of the MR, is the North Atlantic Oscillation (NAO) index. This index is determined by the intensity and position of the Icelandic Low and the Bermuda Azores High and believed to be one of the most important modes of atmospheric circulation for this region. However, the impact of the NAO (Hurrell et al., 2003), is large over the WM but weak and opposite in phase in the Levant. This is manifested by the EM precipitation response to this oscillation which is weak and in antiphase to that in most of the rest of the Mediterranean (Kelley et al., 2012).

A further step toward understanding the association of rainfall anomalies with large-scale, high-amplitude North Atlantic anomalies was undertaken by Eshel and Farrell (2000). They analyzed the mechanisms of EM rainfall variability as controlled by modulations of the relative intensity of the climatological subtropical high and subpolar low, namely, the NAO. Based on rainfall monthly data spanning 1940-1994 for 16 stations over the EM, they examined the differences in large-scale dynamical atmospheric state between the 5 driest and 5 rainiest years. They found that elevated Greenland pressure (i.e., negative NAO phase) is accompanied by an anomalous cyclone over the MB. These

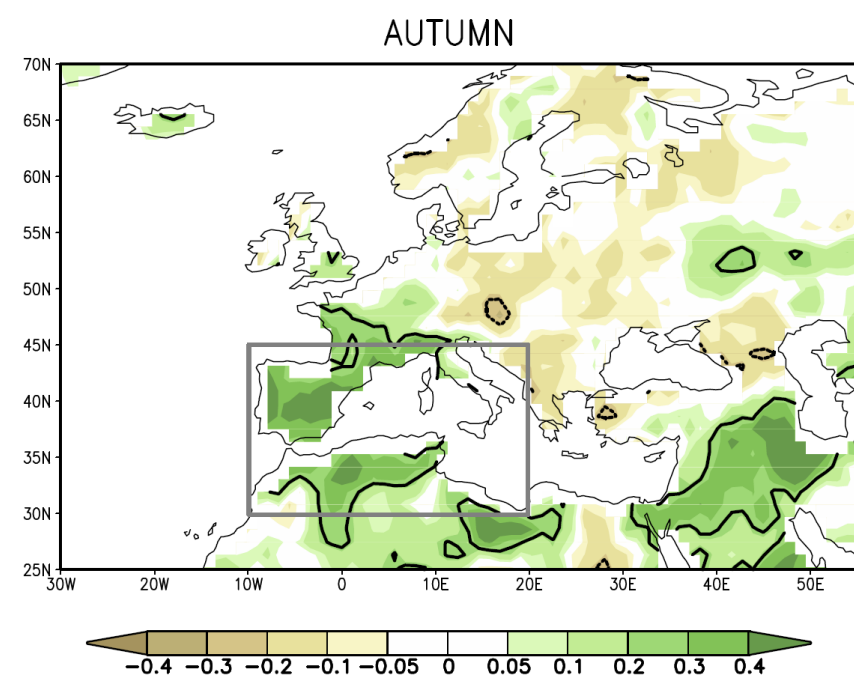

Figure 7. Correlation of rainfall over the WM in fall and the Nino3.4 index for the period 1948-1996 (from Mariotti et al. (2002b), reprinted with permission of John Wiley and Sons).

anomalies result in anomalous southerlies which warm the EM and enhance air-mass ascendance which lead to intensive precipitation.

An investigation of the link between atmospheric circulation patterns and Iberian total rainfall for the period 19581997 led by Goodess and Jones (2002) revealed that the NAO negative mode produces high-pressure blocking in the northeast Atlantic, and a more meridional circulation than the opposite, NAO positive mode, consistent with Moses et al. (1987). Moreover, upper-air troughs and incursions of polar air over the Mediterranean are more frequent and the Atlantic storm tracks are displaced south. They suggest that all these factors are conducive to wetter conditions in the WM. This is in line with Toreti et al. (2010), who analyzed daily extreme precipitation events during the winter season at 20 Mediterranean coastal sites covering the period 1950 to 2006. They showed that western Mediterranean anomaly patterns ( $\mathrm{GPH}$ at $500 \mathrm{hPa}$ and SLP) associated with extreme precipitation events show dipole structures favoring mid-tropospheric southwesterly/westerly flow, which indicates moisture transport from the Atlantic. However, as mentioned previously, the relationship of the NAO and rainfall is not uniform over the whole MB. Cullen and deMenocal (2000) showed that rainfall is negatively correlated with the NAO over most of the basin, while its southeastern parts exhibit a positive correlation. Brandimarte et al. (2011) checked this relationship over two regions in the basin: southern Italy, and the Nile Delta (Egypt), representing western and eastern parts of the $\mathrm{MB}$, respectively. Their results showed a negative correlation over southern Italy and a low, though significant, positive correlation over the Nile Delta which is consistent with Cullen and deMenocal (2000). 
A third prominent teleconnection pattern which has an impact on the MR is the east Atlantic/west Russia (EA-WR) pattern. This pattern consists of two main anomaly centers: a positive phase, associated with positive high anomalies located over the east Atlantic, and negative high anomalies, located over the Caspian Sea. During the negative EA-WR phases, wetter weather conditions are observed over the MR (Barnston and Livezey, 1987). Krichak and Alpert (2005) calculated the space correlations between the mean monthly precipitation and the EA-WR pattern for 1950-2000. They found that precipitation/EA-WR index correlations are statistically significant over the eastern Atlantic and southeastern MR. Further they have demonstrated that the specific space correlation patterns were attributed to periods of high and low EA-WR regimes and associated to typical circulations responsible for precipitation over the EM.

Another northern hemispheric teleconnection pattern that governs the total rainfall variability over the MR is the Scandinavian pattern (SCAND). This pattern consists of a primary circulation center over Scandinavia and weaker centers of opposite sign over western Europe and eastern Russia. The positive phase of the SCAND pattern is associated with positive high anomalies that reflect a major blocking anticyclone over Scandinavia, accompanied by above-average precipitation across southern Europe and the western Mediterranean (Barnston and Livezey, 1987). These results are consistent with Krichak et al. (2014) who found large positive correlations between the frequency of precipitation events and the SCAND pattern over the western Mediterranean region.

So far, we have shown that few modes of variability play a role in the total rainfall rate in the MR, however, despite the considerable efforts devoted to this issue as reflected by the numerous articles published, the influence of teleconnection patterns on very severe rain events is still controversial. Evidence of the role of the NAO on heavy precipitation was demonstrated and studied by Scaife et al. (2008) who found a statistically significant negative correlation between "moderately extreme" precipitation events (i.e., characterized by the $90 \%$ threshold value) and the NAO, for the WM region, using the (EMULATE) database described by Moberg et al. (2006) (Fig. 8). Using the NCEP data set for the winter season, a study by Yiou and Nogaj (2004) confirms this result. Similar patterns of influence for the NAO on extreme precipitation during winter were also found by Kenyon and Hegerl (2010), using station-based climate indices. The results obtained by Krichak et al. (2014), based on a correlation between monthly NAO index and the frequency of "moderately extreme" days of precipitation over western Europe, are consistent with the previous studies. However practically no NAO role in determining frequency of days of extreme precipitation was detected in the EM. As related to the EA-WR pattern, Krichak et al. (2014) found positive (negative) correlations between this pattern and the frequency of "moderately extreme" precipitation, in the eastern (western) Mediterranean. However, higher thresholds values reflecting
Correlations: NAO vs. R90N (DJF) 1901-2000

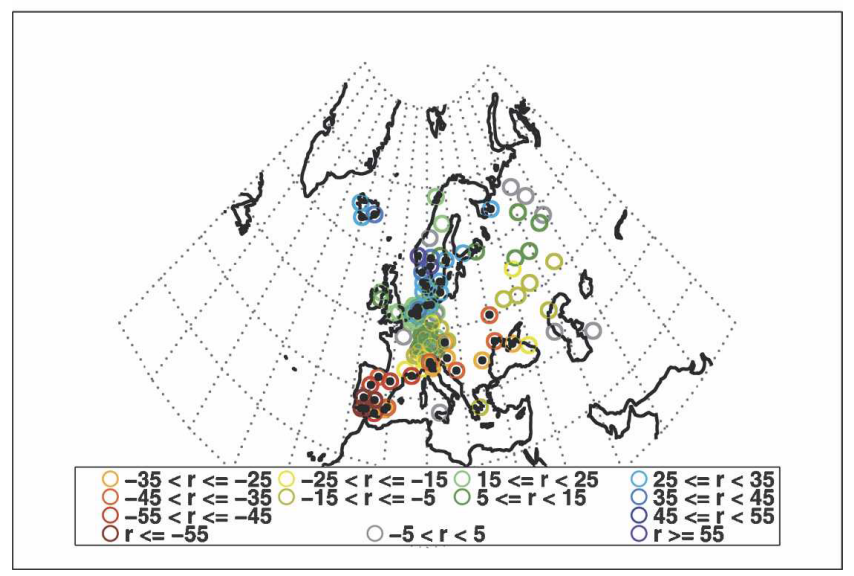

Figure 8. Correlations $(\times 100)$ over the whole twentieth century between the NAO and the frequency of above 90th percentile daily rainfall events. Black dots show stations with correlations significant at the $99 \%$ level accounting for autocorrelation and percentiles that are defined over 1961-1990. All stations that are used have at least 15 years of 90th percentile precipitation data in each 20-year block $(1901-1920,1921-1940, \ldots, 1981-2000)$ west of $60^{\circ} \mathrm{E}$ in the European and North Atlantic daily to MULtidecadal climATE variability project (EMULATE) database described by Moberg et al. (2006) (from Scaife et al. (2008), ${ }^{\circledR}$ American Meteorological Society. Used with permission).

very severe precipitation days (exceeding the 98th percentile threshold) have not shown any association with these teleconnection patterns.

Reale and Lionello (2013) carried out a comprehensive analysis to check whether precipitation events along the Mediterranean coasts, classified according to their severity (i.e., percentile threshold and corresponding frequency) are associated with anomalous phases of the essential north Hemispheric teleconnection pattern described previously (i.e., NAO, EA-WR, and SCAND). They found that, although, NAO and EA-WR are the most influencing patterns over the western and central MRs, respectively, with a similar influence on the frequency of the 25,50 , and 90 percentiles threshold, the 98 percentile threshold is not linked with either phase of these teleconnection patterns.

Beside the longer variations of cyclonic intensity modified by a broader phenomenon of low-frequency Northern Hemisphere atmospheric variations referred to as "teleconnections", year to year variations in total rainfall have been observed in connection with synoptic activity over the Northern Atlantic. Jacobeit (1987) pointed out the strong dependence of Mediterranean cyclogenesis on North Atlantic synoptic activity. Indeed, Trigo et al. (2000) found that the reduction in strength of the most intense cyclones is driven by recent trends observed in the coupled ocean-atmospheric circulation over the Northern Atlantic, in particular by the northwards migration of the main Atlantic storm tracks. 


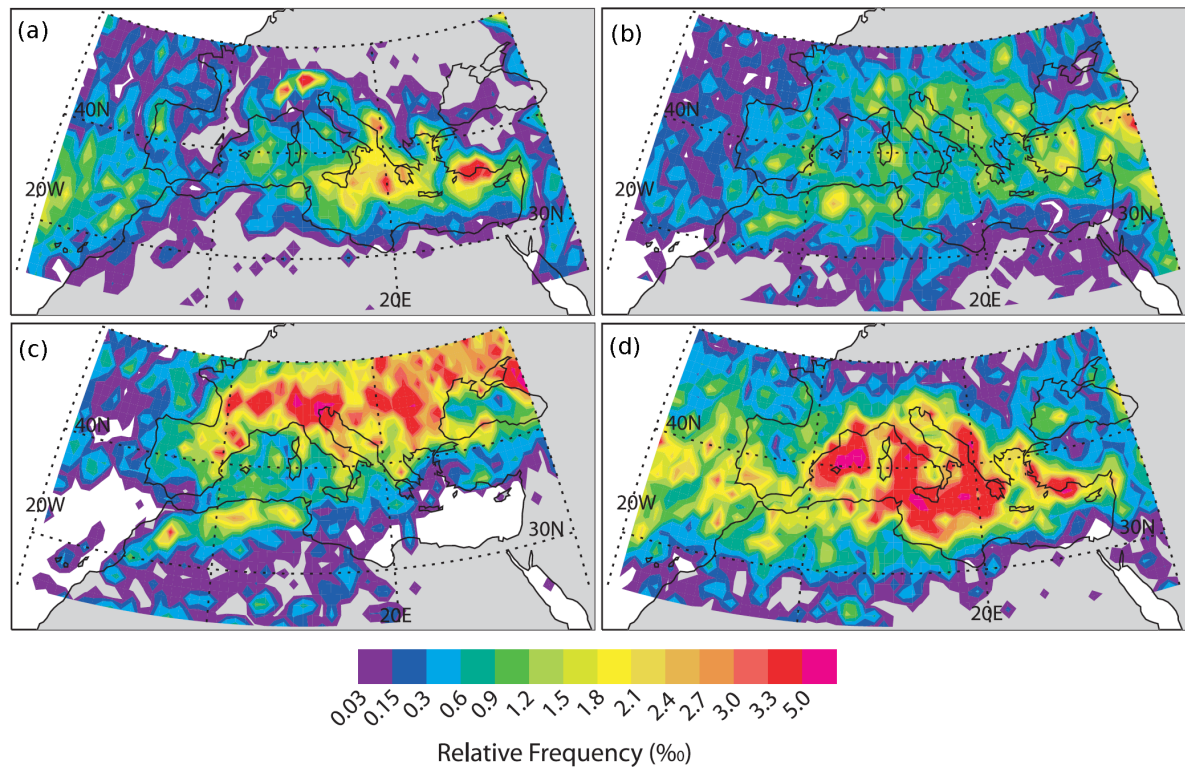

Figure 9. Spatial distribution of the 7-year average seasonal relative frequency of deep convection for the period 2001-2007 over the MB. (a) Dec-Jan-Feb, (b) Mar-Apr-May, (c) Jun-Jul-Aug, and (d) Sep-Oct-Nov (from Funatsu et al. (2009) ${ }^{\circledR}$ American Meteorological Society. Used with permission).

With respect to the most western part of the WM, Zorita et al. (1992) analyzed the interaction of atmospheric circulation and SST in the North Atlantic area in winter with precipitation variability over Iberia. They found that the most dominant process responsible for the variability of total rainfall appears to be the intensity of the westerlies and the frequency of storms embedded in it rather than the presence of regional or remote SST anomalies.

However the role of the SST in the development of torrential rain events is controversial. Millan et al. (1995) argued that enhanced evaporation resulting from temperature differences between European continental air and the relative warm Mediterranean Sea in fall can become a key factor in determining the onset of precipitation. Fernández et al. (1997) stress the importance of knowledge of SST as a critical factor for an accurate model forecasting of mesoscale convective systems (MCS) over the WM in fall. Pastor et al. (2001), based on numerical simulations using a mesoscale model, point out SST's influence on two torrential rain episodes, while using different SST data sets derived from satellite data. In a recent study, Pastor et al. (2015) have shown that regions of high heat/moisture air-sea exchange over the MB are prone to enhancing convection, leading to torrential rain.

As compared to the above-mentioned low-frequency atmospheric circulation patterns that govern total rainfall variability, the mechanism that controls extreme rainfall events stems from the location of cyclonic circulation centers and the dynamical atmospheric state prior and during such extraordinary events. Saaroni et al. (2010) indicated that deep
Cyprus Lows, most contributing to extreme rainfall over the region located to the north and east of Israel, produce the highest amounts of daily rainfall as compared to other synoptic systems, averaging to 16.4 and $10.9 \mathrm{~mm} \mathrm{~d}^{-1}$, respectively, for November-March of 1954-2004.

Fernández-Montes et al. (2014) point out the strong relationship existing between extreme precipitation days, synoptic circulation types, and their associated moisture content. They define extreme precipitation days as days on which the total precipitation amount is above the station-specific 90th percentile of daily precipitation amount on wet days for the 1971-2000 base period. They indicated that over the WR the frequency of such extreme days during fall became more frequent for the period 1950-2003 as a result of an increasing frequency of cyclonic northwest flow. Toreti et al. (2014) used 108 precipitation daily time series for 1961 to 2007 over the northern coastal basin to identify the upper-level atmospheric dynamics of extreme rain events. They highlight potential vorticity (PV) anomalies as main precursors of such extraordinary events in the MR. In a recent study, RavehRubin and Wernli (2015) identified the highest impact largescale extreme precipitation events in the MR integrated over a spatial scale of $1000 \mathrm{~km}$ and a temporal scale of 3 days. They found that the top 10 extreme events for the period 1979-2002 are dynamically characterized by an upper-level trough and strong jet on its western flank, followed by cyclogenesis over the WM and/or merging of the polar with the subtropical jet over the EM. Furthermore and consistent with Toreti et al. (2014), they found that the strong cyclonic 
circulation is located coherently below the high PV anomaly aloft.

\section{Spatial distribution of deep convective precipitation over the MR}

The interaction between the Earth's surface and near-surface atmosphere is critical with respect to the development of intensive convective rainfall events. The heating and moistening of the land surface affects the buoyancy of air parcels that turn to updrafts which might initiate convective rainfall. Colby (1984), using modeling and observations, found that soil moisture had a strong effect on the surface fluxes and on the convective inhibition. Segal et al. (1995) used a onedimensional model to evaluate the impact of surface moisture on the potential for deep convection. Moistening of regions prone to deep convection was found to be contributed to by several concurrent processes: surface evaporation, thermal convection, and boundary layer vertical mixing, increasing the depth of the moist layer (Weckwerth et al., 2014).

For events associated with intense deep convection, it is possible to consider satellite radiation measurements to obtain information about the spatial distribution of intense convective rainfall events. Such an approach was suggested by Funatsu et al. (2009). It is based on measurements with the AMSU-B microwave radiometer on-board NOAA satellites. AMSU-B features 3 channels designed to measure atmospheric moisture. These moisture channels $(3,4$, and 5) detect the presence of hydrometeors through the scattering of radiation, which lowers the brightness temperature compared to its surroundings. Based on these data, Funatsu et al. (2009) identify and detect areas of deep convection over the MR. They suggest a deep convective threshold (DCT) corresponding to an accumulated rainfall of at least $20 \mathrm{~mm}$ in $3 \mathrm{~h}$ in $50 \%$ of the cases in the MR. This threshold was validated by Funatsu et al. (2007a, b) with radar and rain gauges from meteorological ground stations for selected heavy precipitation events.

The spatial distribution of deep convection (Fig. 9) features a pronounced seasonal signal with convective events more frequent over land in summer; these spots of DCT migrate toward the sea in fall, becoming most frequent over the sea in winter. Most active regions for deep convection are the Alps, the western Croatian coast, the south of France and the wider area of Tunisia. Some of these regions coincide with areas characterized as being vulnerable to heavy precipitation that induces floods over the MR (Harats et al., 2010). Claud et al. (2012) and Alhammoud et al. (2014) have extended the data set using measurements from the AMSU$\mathrm{B}$ and the Microwave Humidity Sensor instruments onboard additional NOAA satellites. They found that interannual variability of deep convection is strongest along the northern coasts of the MB. While there is less variability over the sea. Alhammoud et al. (2014) found a maximum frequency of deep convection over the MB in September-October and a minimum one in June and July, which is consistent with Funatsu et al. (2009) and Melani et al. (2013).

\section{Synoptic circulation patterns that induce heavy rain}

Several studies analyzing the important role of synoptic forcing on the generation of extreme precipitation over the MR have been previously conducted, (e.g., Lionello et al., 2006; Ulbrich et al., 2012; Xoplaki et al., 2012; Lionello, 2012). The typical components leading to heavy rainfall are an unstable air mass, a moist low-level jet, the presence of orography orthogonal to the flow, and a slowly evolving cyclonic synoptic pattern (Doswell III, 1998; Miglietta and Rotuno, 2010). Even though occurrence of heavy precipitation events are not always attributed directly to intense cyclones, for most of the cases, a surface cyclone is usually positioned at a distance of few hundreds of kilometers to the heavy rain region (e.g., Jansa et al., 2001; Reale and Lionello, 2013; Raveh-Rubin and Wernli, 2015). For this reason, gaining insights into the synoptic climatology of cyclones for the whole MB (i.e., seasonal frequency, spatial distribution and regions favoring cyclogenesis) is important. A significant contribution to this task is the comprehensive paper (Campins et al., 2011) and the MEDEX database as part of the MEDEX program (Jansa et al., 2014).

In the EM, high rain depths are often associated with active cold fronts, in turn linked to mid-latitude extratropical cold lows originating over the eastern part of the basin (e.g., the Cyprus Lows; Fig. 6a). The flow associated with these lows may lead to heavy precipitation over the Levant region as a result of forced convection while crossing mountain ridges. Intensive rainfall in the southernmost parts of the EM is generated mainly by a derivative of the Cyprus Low - the Syrian Low. Syrian Lows (SL) are Mediterranean mid-latitude cyclones that deepen while approaching Syria (Kahana et al., 2002). SLs are the second most frequent synoptic-scale cyclone type, producing major floods over the southern part of the region (Kahana et al., 2002, 2004). An objective selection of all EM cyclones for four consecutive winters (19821986) undertaken by Alpert and Neeman (1992) found that such Syrian cold cyclones are slightly more baroclinic and feature larger than average latent heat fluxes, which indicates the importance of local convection.

In contrast to the Mediterranean mid-latitude cyclones, the Red Sea trough (RST) is one such tropical system incursion, characterized by a low barometric trough that extends northward from equatorial Africa, crossing the Red Sea and the EM regions. Occasionally, under specific upper air support conditions, this synoptic-scale system can become active and generate stormy weather with intense precipitation, referred hereafter as an active Red Sea trough (ARST) (Dayan and Morin, 2006). This tropical system, accounting for most of the major floods over the southeastern EM (Kahana et 
(a)
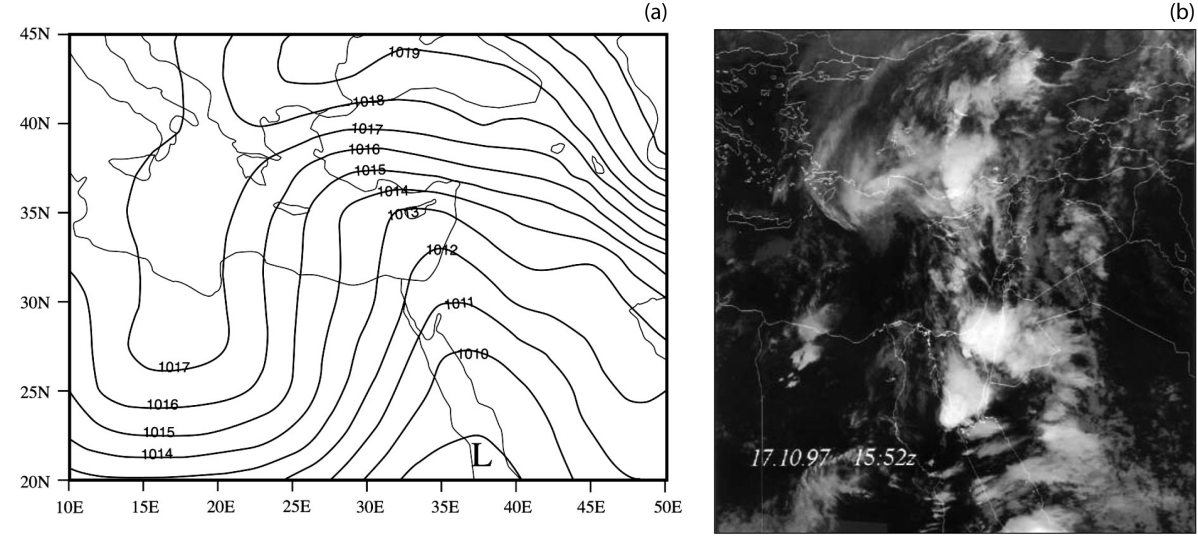

Figure 10. (a) Composite SLP with an interval of $1 \mathrm{hPa}$ for all flash flood cases resulting from the ARST synoptic category. (b) US National Oceanic \& Atmospheric Administration satellite IR image (NOAA Satellite and Information Service, http://www.nesdis.noaa.gov/ satellite.html) for a developing mesoscale convective system over the southeastern MB at 15:52 UTC on 17 October 1997 (from Dayan and Morin (2006) with permission to reprint from the Geological Society of America).

al., 2002), occurs mainly during fall (Dayan et al., 2001). The ensuing destabilization of the lower troposphere leads to a rapid formation of deep convective clouds embedded in severe mesoscale convective systems (MCS) that produce heavy precipitation and thunderstorms (Fig. 10a, b).

The southerly winds over the EM at the $500 \mathrm{hPa}$ level were found to be essential for the moisture transport of tropical origin to the region. The knowledge gained from detailed synoptic-scale analysis of several rainstorms associated with an ARST that has impacted the southern EM (Dayan et al., 2001; Ziv et al., 2004; Krichak et al., 2012) provides a basis for the generalization of the main characteristics of this synoptic system. In all cases, the storm was initiated while hot and dry air blew from the east at lower levels, leading to a buildup of conditional instability throughout the troposphere. All these storms, in their initial stage, were characterized by a MCS with an intensive warm core moving from Sinai Peninsula northward over the Negev Desert and the Dead Sea Basin (Fig. 10b).

The physical characteristics of MCSs were defined on the basis of enhanced infrared satellite imagery developed by Maddox (1980) and appear as a large circular region composed of high clouds that gradually become colder and higher toward the center of the system (Fig. 10b). Such precipitative elements crossing the southeastern parts of the EM can produce intense rainfall that induces floods due to their large aerial extent and long duration. As stated in Sect. 3, over the southeastern Mediterranean the STJ can serve as a conveyor belt of moisture in middle and upper tropospheric layers, often originating from tropical Africa. In addition to this important role, the synergistic interaction of these jets with the midtropospheric diabatic processes assists in intensifying cyclogenesis and contributes significantly to deep synoptic-scale ascent over the region (Ziv et al., 2004). Dayan et al. (2001) analyzed an intense rainstorm that struck the EM in October
1997. The storm was manifested by torrential rain with intensities of a 30 -year return time that exceeded $100 \mathrm{~mm} \mathrm{~h}^{-1}$ for 10 min over Jericho in the northern part of the Dead Sea, Israel. In addition to the conditional instability established by the preexistence of the Red Sea barometric trough, the upperlevel divergence imparted by both polar jet (PJ) and STJ over the region supported the formation and intensification of this storm. The EM was then situated simultaneously to the left of the STJ exit and to the right of the PJ entrance, implying near-tropopause divergence.

As compared to the EM characterized by less frequent cyclogenesis in the fall months, heavy precipitation in the WM usually occurs in fall, since the Mediterranean SSTs are still high from the summer heating. Jansa et al. (2000) pointed out the frequent formation of lee depressions and troughs over the warm and humid air that fills this part of the basin. The combination of strong synoptic-scale forcing and the contributing topographic features makes the WM prone to heavy rains caused by MCSs embedded in synoptic-scale systems as confirmed by Rudari et al. (2005) by means of a large ensemble of heavy rainfall events and composite statistics. The examination of four heavy rainfall events that occurred in the coastal area of northeastern Italy, a region fringed by the Alpine barrier to the north of the Adriatic Sea, revealed that synoptic rather than convective settings controlled the observed timescales of these intense rainfall events. The combined convective rainfall rates paired with the synoptic durations led to the exceptionally high rainfall accumulations observed (Barbi et al., 2012). In some particular cases, daily amounts of precipitation of 300,400 , and even $800 \mathrm{~mm}$ have been reported in that particular region (see, for example, Romero et al., 1997; Ramis et al., 1998). Extreme rainfall events over northwest Italy were classified, taking local station intensities and rainfall durations simultaneously into account (Pinto et al., 2013). The two clusters containing the 
strongest events were found to be associated with strong and persistent upper air troughs, inducing not only moisture advection from the North Atlantic into the WM but also strong northward flow towards the southern Alpine ranges. Other favorable large-scale conditions for the occurrence of deep convection in their target area are the location in front of the upper air trough, and enhanced humidity available over the WM region shortly before the event. A sustained moisture advection towards the southern Alpine ranges is due to a quasi-stationary steering low located near the Bay of Biscay/British Isles, while local cyclogenesis over the WM region is responsible for triggering and focusing the event on a particular area. The authors find their characterization in agreement with investigations of heavy rainfall for Catalonia (Rigo and Llasat, 2007), and for the broader WM (Jansa et al., 2001 and Martinez et al., 2008).

Other parts of the WM and the northern parts of the Adriatic Sea are also occasionally affected by very heavy rain (see, for example, Senesi et al., 1996; Buzzi et al., 1998). Ducić et al. (2012) carried out an analysis of the relationship between extreme precipitation events and synoptic circulation types in Montenegro, the wettest Mediterranean region. In their study, they used an efficiency coefficient, expressing the ratio between a relative frequency of a given circulation type in extreme precipitation events to its mean frequency for the period spanning 1951-2007. They found that northerly, easterly, and southerly circulation types are more frequent for very wet days. Doswell III et al. (1998) examined three heavy precipitation events that occurred over the WM and pointed out the difference among them in spite of their perceived similarities. Although these events were characterized by a southerly flow, advecting warm and moist air at the surface accompanied by an eastward movement of a midtropospheric trough, and leading to a positive vorticity over the whole WM, evolutionary differences were found among them. The synoptic condition responsible for the heavy rain during the Piedmont event analyzed by Jansa et al. (2000) was the presence of a middle- to upper-level trough, drifting northeast from Spain, forcing an upward motion. A frontal structure at shallow levels provided the additional upward motion. A strong southwesterly flow in the forefront of the frontal structure blew perpendicular to the local orography. This vigorous upslope forcing imposed by the Apennines and the Maritime Alps, combined with the convective instability over the sea were the critical factors for the heavy rain.

Jansa et al. (2001) checked the simultaneities existing between heavy rain and surface cyclones over the WM covering the period from December 1991 to November 1996. They found that for about $90 \%$ of all heavy rain cases $\left({ }^{\circ} 60 \mathrm{~mm} / 24 \mathrm{~h}\right)$, a cyclone center is usually around $300 \mathrm{~km}$ to the heavy rain region. Analyzing intense precipitation in winter for 15 coastal sites around the MB, Reale and Lionello (2013) found that the probability of finding a cyclone within a distance of $20^{\circ}$ (approx. $2000 \mathrm{~km}$ ) from a precipitation event increases with the intensity of the event. Romero et al. (1999b) investigated the synoptic circulation associated with typical spatial patterns for significant rainfall days for the Spanish Mediterranean area for 1964-1993. Among the 19 derived synoptic types obtained from a cluster analysis of heavy rainfall days and spatial modes of the 500 and $925 \mathrm{hPagph}$, they found that the most effective ones are the circulation types during which a large-scale disturbance is located to the west or south of the Iberian Peninsula while generating a moist Atlantic flow, enhancing copious rainfall over the WM.

Romero et al. (1999b) derived eight characteristic torrential rainfall patterns (defined when at least $2 \%$ of the 410 Iberian stations registered more than a daily amount of $50 \mathrm{~mm}$ ) and found that most torrential rain days occur whenever an accentuated mid-tropospheric trough or a closed cyclone is located to the south or west of the Iberian Peninsula and accompanied by a collocated low at shallow tropospheric layers. Among the numerous baroclinic low pressure systems generating intense precipitation, a few are tropical-like cyclones which are formed during the cold season, mainly over the WM and referred to as "medicanes". However, the latter are extremely rare $(0.75$ p.a. over the WM and 0.32 p.a. over the Ionian Sea) (Miglietta et al., 2013; Cavicchia et al., 2014). Numerous diagnostic and numerical studies, reflecting similar synoptic conditions that induce heavy rain over this part of the MR, have been published (e.g., Doswell III et al., 1998; Ramis et al., 1994, 1999, 2009; Homar and Stensrud, 2004). In a general context, the main atmospheric circulation patterns that produce heavy rainfall over both eastern (Levy et al., 2008) and western (Romero et al., 1999b) tips of the MB are displayed (Table 1).

Nuissier et al. (2008) best summarize this section as deduced from their study examining the simulation of three torrential rain events over southeastern France while stating: "even though synoptic-scale ingredients (upper-level PV anomalies, strong low-level moisture advection, CAPE, etc.) can provide the necessary ingredients for the convective activity, other important mesoscale factors and/or finer-scale processes contribute to continuously focus the activity over the same specific region (the necessary forced ascent to trigger and/or maintain the convection)". Moreover, simulations of extreme rainfall events are very sensitive to the details and precise timing of these mesoscale factors, despite their being embedded in a large-scale synoptic system (Argence et al., 2008; Ducrocq et al., 2008; Fiori et al., 2014).

\section{Thermodynamic and dynamic predictors of heavy precipitation}

The occurrence of torrential rains and thunderstorms and their intensity depends on a combination of factors, such as temperature profiles and implied instability, atmospheric moisture, lower-level convergence etc. In order to evaluate the probability and intensity of the rainstorm, various pre- 
Table 1. Main atmospheric circulation patterns that produce heavy rainfall over both eastern (Levy et al., 2008) and western (Romero et al., 1999b) tips of the MB.

Western tip of MB (western Mediterranean Spain); Romero et al. (1999b)

\begin{tabular}{|c|c|c|c|}
\hline Circulations types & Season & Flow direction & Regions affected \\
\hline Low to the $\mathrm{W}$ and NW of Iberia & Fall, winter & W humid Atlantic & Western Andalucia \\
\hline Cold front from low $\mathrm{N}$ of Iberia & Fall, winter, spring & $\mathrm{W}$ & NE Spain \\
\hline Low to the south of Spain & Winter, spring, summer & E-SE humid Mediterranean & E Spain, Balearic Islands \\
\hline Low to the $\mathrm{E}$ of Iberia & Winter, spring & $\mathrm{N}$ & NE Iberia, Balearic Islands \\
\hline \multicolumn{4}{|c|}{ Eastern tip of MB (Israel and Levant coast); Levy et al. (2008) } \\
\hline Deep Cyprus Low to the north & Winter & $\mathrm{W}$ & Whole EM coast \\
\hline Shallow Syrian Low & Winter & NW & SE Mediterranean \\
\hline Red Sea trough with western axis & Fall & SE & SE Mediterranean \\
\hline
\end{tabular}

(a)

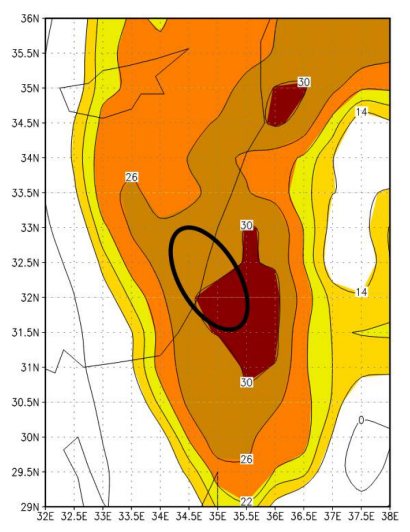

(b)
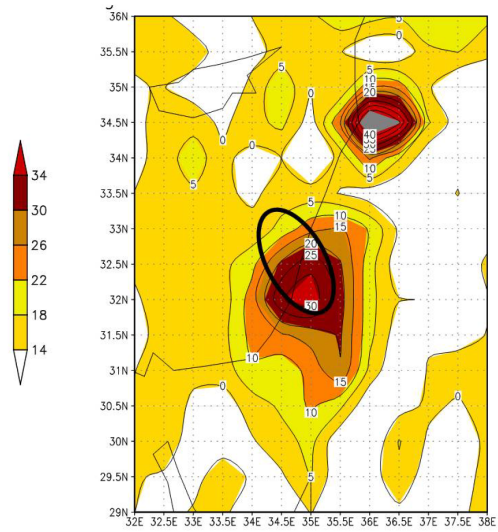

(c)

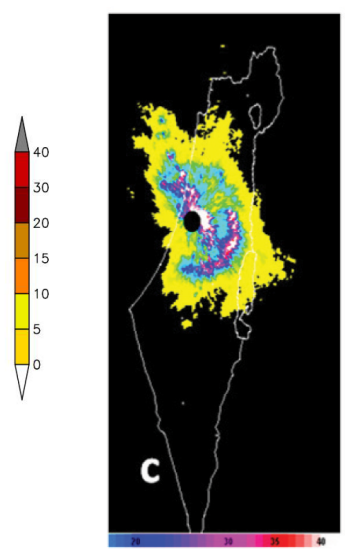

Figure 11. Spatial distribution of (a) MKI, (b) RDI, both for 2 April 2006, 00:00 UTC, and (c) uncalibrated rain totals derived from the radar reflectivity over the period 1 April 2006, 23:00 UTC-2 April 2006, 01:00 UTC. The bold ellipses in (a) and (b) represent the core of the rain system. (from Harats et al. (2010) Open Access).

dictors should be combined to estimate the necessary conditions for its occurrence. In a first attempt, Dayan and Sharon (1980) found that indices of instability were the most efficient determinants over the EM, as is the qualitatively defined synoptic situation. Vorticity and water content of the air proved to be similar for widespread and spotty types of storms. Predictors for the ARST and the Syrian Low (see Sect. 7 above) were examined by Kahana et al., 2004. For the ARST synoptic condition, most of the predictors were found at the $500 \mathrm{hPa}$ level, with the most powerful being the $v / u$ ratio, which represents the southerly wind component that is responsible for the transport of moist tropical air masses towards the EM. Two new indices, aimed to assess the potential for heavy precipitation and flash floods over the EM, were proposed and evaluated by Harats et al. (2010). The first is the MKI, which is a modified version of the KI index (Mortimer et al., 1980):

$\mathrm{MKI}=\left(T_{500}-T_{850}\right) \times \mathrm{RH}_{850,700}+T_{\mathrm{d} 850}-\left(T_{700}-T_{\mathrm{d} 700}\right)$, where $T$ and $T_{\mathrm{d}}$ are the dry bulb and dew point temperatures, respectively, and the subscripts refer to the respective pressure level (hPa). The first term reflects the lapse rate throughout the lower and middle troposphere (the lapse-rate term), which is multiplied by the average $\mathrm{RH}$ of the 850 and $700 \mathrm{hPa}$ levels; the second represents the lower-level moisture; and the third the saturation deficit in the mid-troposphere. The applied index gives more weight to the lower- and mid-level relative humidity. The second index suggested by Harats et al. (2010) is a rain index, the RDI, which is the integrated product of specific humidity and vertical velocity.

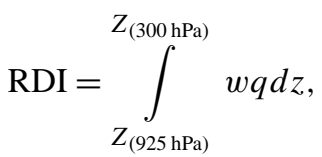

where $w$ is vertical velocity, $q$ is specific humidity and $z$ is elevation. This index comprises the precipitable water and the dynamic conditions necessary to convert it to rain. Figure 11 displays the spatial distribution of these two indices as cal- 
culated for the torrential rain event that occurred on 1 April 2006 along a northwest-southeast-orientated line extending from the central coast of Israel (Wadi Ara) to the northern end of the Dead Sea. Based on the few cases analyzed in this study Harats et al. (2010) suggest that the tentative values of 25 for the MKI and of 20 for the RDI might be referred to as preliminary thresholds for rain storms and potential flash floods over the EM.

As compared to the EM, for which heavy precipitation is associated mostly with frontal thunderstorms occurring mainly in winter, the central and WM are often affected by non-frontal (air-mass) thunderstorms. Such convective weather events and especially heavy rains are frequent during fall. Forecasting these severe weather conditions is based, among other tools, on a broad range of stability indices and thermodynamic parameters. Jacovides and Yonetani (1990) used a coastal and inland location in the MR to evaluate the skill of a combination of indices, namely, the humidity index (Lintynska et al., 1976), the Pickup index (Pickup, 1982), and the $K$-stability index (Reap and Foster, 1979) and compared them to the modified Yonetani index. This last index combines information about the lapse rates of the 900-850 and $850-500 \mathrm{hPa}$ layers with a measure of the mean relative humidity of the $900-850 \mathrm{hPa}$ layer. They have shown, after adding the flow curvature at $500 \mathrm{hPa}$, that the Yonetani index is more successful than the others in the forecast of air-mass thunderstorms over the MR.

Several researchers (e.g., Neuman and Nicholson, 1972; Fuelberg and Biggar, 1994) have made attempts to classify convective events into separated groups, based on the observed events (hail, heavy rain, "dry" storms, storms with heavy rain, and tornadoes) while using single-stability indices to differentiate between groups. The usage of such classic stability indices did not provide good guidance for distinguishing environments associated with each group of events.

An alternative approach to classify the environments in which significant convective events occur has been made by Tuduri and Ramis (1997). In their study, soundings have been defined by means of 34 variables that include the vertical distribution of temperature, humidity, instability, helicity, and precipitable water. The $k$-means clustering method has been used to determine four different environments including a "heavy rain" category. Their results point out particular environments that characterize the different events. In such a way, heavy rain events occur with warm, humid air in the whole troposphere and warm advection at low levels. Moreover, they demonstrated that convective indices are very sensitive to the location due to the nature of thunderstorms that induce heavy rain; thunderstorms are the ones characterized by a high spatial and temporal variability. Obviously, beside convection and moisture supply, a mechanism for sustaining this convection is necessary in order to originate intense precipitation.

Recently, Korologou et al. (2014) developed an index as a predictor of heavy convective rainfall over western Greece.
This index, referred to as the local instability index (LII), takes into account the three essential components for the initiation of thunderstorms and heavy rains: energy, moisture, and a lifting mechanism. The advantage of the LLI is the incorporation of experience-based local weather and knowledge of atmospheric processes associated with severe thunderstorm events. It is, however, not clear if any of the suggested parameters result in a better general performance in indicating a high risk of heavy rainfall events than those developed earlier.

Both the previous section and this section have shown clearly that extreme precipitation in the MR is inevitably related to two essential interlaced mechanisms: advection, attributed to large-scale circulation dynamics, and convection, driven by thermodynamics of the atmosphere. In an attempt to quantify the relative contribution of each of these mechanisms to the possible evolution of extreme precipitation, Hertig et al. (2014) used two general circulation models to assess the projected changes of extreme precipitation in the MR until the end of the twenty-first century by means of statistical downscaling. They found that large-scale circulation plays an important role in the generation of extreme precipitation events in the transitional seasons. Furthermore, in the winter the number of events exceeding the 95th percentile of daily precipitation for the period 1961-1990 is governed by the moisture availability in the lower troposphere and by the large-scale circulation, represented by the geopotential heights of the $700 \mathrm{hPa}$ level and the zonal wind component of the $850 \mathrm{hPa}$ level. In general, for regions characterized by reduced total precipitation amounts and high interannual precipitation variability, such as summer in eastern and southern Mediterranean areas, it was more difficult to assess the relative role of convection versus advection.

\section{Summary}

There are substantial regional differences in rain rates over the MR. The maximum rainfall occurs over the mountain regions in the north Mediterranean coasts while the minimum rainfall is over north Africa. The main rainy season over this region, including the western coast of north Africa, extends from September to May, but maximum rainfall occurs during November-December. Over the northern Mediterranean, there is a bimodal rain pattern, with spring and fall seasons having maximum rainfall. The rainy season over the eastern coast of northern Africa (southern Mediterranean) and the EM is December-January-February, while most heavy precipitation events in the WM occur in fall.

In both sub-Mediterranean basins most of the heavy rain events (around 90\%) are associated with a cyclone in the vicinity that generates a flow of air towards the area affected by heavy rain. The main tracks of migrating lows in winter are over the northern MB, whereas in the summer, the blocking effect of the Azores High and the subsiding condi- 
tions aloft prevent the movement of cyclones as well as their formation mostly over the EM. Contributing factors to the Mediterranean cyclogenesis are the relatively elevated SST and the diabatic heating from condensation which serves frequently as a determinant in Mediterranean cyclones. Most intense EM rain episodes are associated with the cold fronts of mid-latitude cyclones (i.e., Cyprus Lows and Syrian Lows) that affect the eastern and southeastern Mediterranean coasts, respectively, in winter. In fall, the ARST tropical synopticscale system accounts for most heavy and localized precipitation events, mainly over the eastern and southern parts of the Levant.

In comparison to the EM, fall is the season of frequent heavy precipitation spells over the WM. These events are often associated with lee cyclogenesis over the relatively warm and moist air filling this part of the basin. The typical synoptic configuration of a heavy precipitation episode is an eastward-advancing trough, which leads to positive vorticity advection in the mid-tropospheric layer accompanied by a deep cyclone positioned over the WM at the surface, generating a strong and moist flow which blows perpendicular to the local orography.

The spatial distribution of deep convection detected objectively by remote sensing and validated with radar and rain gauges over the MR demonstrates a pronounced seasonal signal with convective events more frequent over land in summer, which migrate toward the sea in fall, and are most frequent over the sea in winter. Most frequent regions of deep convection are the western Croatian coast, the south of France and the Tunisian coast.

Moisture not originating from the Mediterranean Sea is the major moisture supply for heavy rain events associated with winter Mediterranean cyclones over the EM. During winter, conveyor belts of moisture in mid-tropospheric layers, called "tropical plumes"/"atmospheric rivers", often originating from tropical Africa, might also play an important role. During the transitional seasons, the Red Sea quite often serves as a corridor for transporting moist air masses from the Arabian Sea and tropical Africa into the southeastern Mediterranean. Over the WM, for most cases, the circumstance under which moisture is supplied is a southerly flow at all atmospheric levels blowing at the forefront of a sharp and slow-moving mid-tropospheric synoptic-scale trough. Under these conditions, the air parcel is orographically forced, destabilized and moistened while crossing the relatively warm Mediterranean Sea which produces the heavy precipitation events. During fall and winter about $10 \%$ of heavy precipitation events in the WM are associated with moisture of tropical origin transported into the region by TPs.

With respect to large-scale teleconnection patterns related to heavy precipitation in the MR, it is widely accepted that the NAO and EA-WR are the most influencing northern hemispheric teleconnection patterns. However, their relationship with rainfall is not uniform over the whole MR. Their impact is large over the WM region and weaker and opposite in phase over the EM region, even though the highest torrential rain events recorded over the MR were not found to be evidently linked with either phase of these teleconnection patterns.

The interannual variation of rainfall, manifested by moisture flux anomalies over the WM, was also found to be related to major ENSO events in fall.

Meteorological indices, developed mainly for forecasting severe weather that induces torrential rain, are combinations of variables, taking instability, atmospheric moisture, and lower-level convergence into account. Such indices often depend on the resolution of the data set and the location they are applied to, but can be useful to predict timing and spatial distribution of heavy precipitation events. In tropical rainbearing circulation systems over the EM, such as the ARST, the southerly wind component at mid-tropospheric levels responsible for the transport of moist tropical air masses (essential for convection) was found to be the most powerful for intense rain events. One of the essential components which lead to torrential rains over the WM, as reflected in most of the indices, point to onshore unstable flow being a major contribution. This indicates that the favorable conditions for torrential rains occur whenever onshore flow of unstable air encounters the mountain ridges in the vicinity of the WM coasts.

Acknowledgements. The authors gratefully acknowledge support from the Center of International Cooperation of the Free University of Berlin. Katrin Nissen was funded by the EU RAIN research project (Seventh Framework Program contract no. 608166). The authors would also like to thank, Michal Kidron from the Department of Geography of the Hebrew University of Jerusalem for her assistance in the preparation of the figures.

Edited by: P. Lionello

\section{References}

Alhammoud, B., Claud, C., Funatsu, B. M., Beranger, K., and Chaboureau, J. P.: Patterns of Precipitation and Convection Occurrence over the Mediterranean Basin Derived from a Decade of Microwave Satellite Observations, Atmosphere, 5, 370-398, doi:10.3390/atmos5020370, 2014.

Alpert, P. and Neeman, B. U.: Cold small-scale cyclones over the Eastern Mediterranean, Tellus, 44A, 173-179, 1992.

Alpert, P. and Ziv, B.: The Sharav cyclone: observations and some theoretical considerations, J. Geophys. Res., 94, 18495-18514, 1989.

Alpert, P., Neeman, B. U., and Shay-El, Y.: Climatological analysis of Mediterranean cyclones using ECMWF data, Tellus, 42A, 6577, 1990a.

Alpert, P., Neeman, B. U., and Shay-El, Y.: Intermonthly variability of cyclone tracks in the Mediterranean, J. Climate, 3, 1474-1478, 1990b. 
Alpert, P., Ben-Gai, T., Baharad, A., Benjamini, Y., Yekutieli, D., Colacino, M., Diodato, L., Ramis, C., Homar, V., Romero, R., Michaelides, S., and Manes, A.: The paradoxical increase of Mediterranean extreme daily rainfall in spite of decrease in total values, Geophys. Res. Lett., 29, 31-1-31-4, 2002.

Argence, S., Lambert, D., Richard, E., Chaboureau, J.-P., and Söhne, N.: Impact of initial condition uncertainties on the predictability of heavy rainfall in the Mediterranean: a case study, Q. J. Roy. Meteorol. Soc., 134, 1775-1788, doi:10.1002/qj.314, 2008.

Barbi, A., Monai, M., Racca, R., and Rossa, A. M.: Recurring features of extreme autumnall rainfall events on the Veneto coastal area, Nat. Hazards Earth Syst. Sci., 12, 2463-2477, doi:10.5194/nhess-12-2463-2012, 2012.

Barnston, A. and Livezey, R. E.: Classification, seasonality and persistence of low frequency circulation patterns, Mon. Weather Rev., 115, 1083-1126, 1987.

Brandimarte, L., Di Baldassarre, G., Bruni, D’Odorico, P., and Montanari, A.: Relation between the North-Atlantic Oscillation and Hydroclimatic Conditions in Mediterranean Areas, Water Resour Manage 25, 1269-1279, doi:10.1007/s11269-010-97425, 2011.

Buzzi, A., Tartaglione, N., and Malguzzi, P.: Numerical simulation of the 1994 Piedmont Flood: Role of orography and moist processes, Mon. Weather Rev., 126, 2369-2383, 1998.

Campins, J., Genoves, A., Picornell, M. A., and Jansa, A.: Climatology of Mediterranean cyclones using the ERA-40 dataset, Int. J. Climatol., 31, 1596-1614, 2011.

Cavicchia, L., von Storch, H., and Gualdi, S.: Mediterranean tropical-like cyclones in present and future climate. J. Climate, 27, 7493-7501, doi:10.1175/JCLI-D-14-00339.1, 2014.

Claud, C., Alhammoud, B., Funatsu, B. M., Lebeaupin Brossier, C., Chaboureau, J.-P., Béranger, K., and Drobinski, P.: A high resolution climatology of precipitation and deep convection over the Mediterranean region from operational satellite microwave data: development and application to the evaluation of model uncertainties, Nat. Hazards Earth Syst. Sci., 12, 785-798, doi:10.5194/nhess-12-785-2012, 2012.

Colby, F. P.: Convective inhibition as a predictive of convection during AVE-SESAME II, Mon. Weather Rev., 112, 2239-2252, 1984.

Conté, M., Giuffrida, A., and Tedesco, S.: The Mediterranean oscillation-Impact on precipitation and hydrology in Italy. Conference on: Climate and Water, Publications of the Academy of Finland, Helsinki, 11-15 September 1989, 121-137, 1989.

Cullen, H. M. and deMenocal, P. B.: North Atlantic influence on Tigris-Euphrates streamflow, Int J. Climatol., 20, 853-863, 2000.

Dayan, U. and Morin, E.: Flash Flood-Producing rainstorms over the Dead Sea, Israel: A Review, in Enzel, Y., Agnon, A., and Stein, M., eds., New Frontiers in Dead Sea paleoenvironmental research: Geological Society of America Special Paper 401, doi:10.1130/2006/2401(04), 2006.

Dayan U. and Rodnizki, J.: The temporal behavior of the atmospheric boundary layer in Israel. J. Appl. Meteorol., 38, 830-836, 1999.

Dayan, U. and Sharon, D.: Meteorological parameters for discriminating between widespread and spotty storms in the Negev. Israel J. Earth Sci., 29, 253-256, 1980.
Dayan, U. and Abramski, R.: Heavy rain in the Middle-East related to unusual jet stream properties. Bull. Am. Meteorol. Soc. 64, 1138-1140, 1983.

Dayan, U., Ziv, B., Margalit, A., Morin, E., and Sharon, D.: A severe autumn storm over the Middle-East: Synoptic and Mesoscale convection, Theor. Appl. Climatol., 69, 103-122, 2001.

Dayan, U., Lifshitz-Goldreich, B., and Pick, K.: Spatial and structural variation of the atmospheric boundary layer during summer in Israel-Profiler and Rawinsonde measurements, J. Appl. Meteorol., 41, 447-457, 2002.

Delrieu, G., Nicol, J., Yates, E., Kirstetter, P. E., Creutin, J. D., Anquetin, S., Obled, C., Saulnier, G. M., Ducrocq, V., Gaume, E., Payrastre, O., Andrieu, H., Ayral, P. A., Bouvier, C., Neppel, L., Livet, M., Lang, M., Parent du-Châtelet, J., Walpersdorf, A., and Wobrock, W.: The catastrophic flash-flood event of 8-9 September 2002 in the Gard Region, France: A first case study for the Cevennes-Vivarais Mediterranean Hydrometeorological Observatory, J. Hydrometeor., 6, 34-52, 2005.

De Zolt S., Lionello, P., Nuhu, A., and Tomasin, A.: The disastrous storm of November 1966 on Italy, Nat. Hazards Earth Syst. Sci., 6, 861-879, doi:10.5194/nhess-6-861-2006, 2006.

Doswell III, C. A.: The distinction between large-scale and mesoscale contribution to severe convection: A case study example, Weather Forecast., 2, 3-16, 1987.

Doswell III, C. A., Ramis, C., Romero R., and Alonso, S.: A diagnostic study of three precipitation episodes in the western Mediterranean region, Weather Forecast., 13, 102-124, 1998.

Drumond, A., Nieto, R., Hernandez, E., and Gimeno, L.: A Lagrangian analysis of the variation in moisture sources related to drier and wetter conditions in regions around the Mediterranean Basin, Nat. Hazards Earth Syst. Sci., 11, 2307-2320, 2011, http://www.nat-hazards-earth-syst-sci.net/11/2307/2011/.

Ducić, V., Luković , J., Burić, D., . Stanojević, G., and Mustafić, S.: Precipitation extremes in the wettest Mediterranean region (Krivosije) and associated atmospheric circulation types, Nat. Hazards Earth Syst. Sci., 12, 687-697, doi:10.5194/nhess-12687-2012, 2012.

Ducrocq, V., Nuissier, O., Ricard, D., Lebeaupin, C., and Thouvenin, T.: A numerical study of three catastrophic precipitating events over southern France. Part II: Mesoscale triggering and stationarity factors, Q. J. Roy. Meteor. Soc., 134, 131-145, 2008.

Duffourg, F. and Ducrocq, V.: Origin of the moisture feeding the Heavy Precipitating Systems over Southeastern France, Nat. Hazards Earth Syst. Sci., 11, 1163-1178, doi:10.5194/nhess-111163-2011, 2011.

Egger, J., Alpert, P., Taffner, A., and Ziv, B.: Numerical experiments on the genesis of Sharav cyclones: idealized simulations, Tellus, 47A, 162-174, 1995.

Eshel, G. and Farrell, B. F.: Mechanisms of Eastern Mediterranean rainfall variability, J. Atmos. Sci., 57, 3219-3232, 2000.

Feldstein, S. and Dayan, U.: Circumglobal teleconnections and wave packets associated with Eastern Mediterranean precipitation, Q. J. Roy. Meteor. Soc., 134, 455-467, 2008.

Fernández, C., Gaertner, M. A., Gallardo, C., and Castro, M.: Simulation of a long-lived meso-beta scale convective system over the Mediterranean coast of Spain. Part II: Sensitivity to external forcings, Meteor. Atmos. Phys., 62, 179-200, 1997.

Fernández-Montes, S., Seubert, S., Rodrigo, F. S., Rasilla Álvarez, D. F., Hertig, E., Esteban, P., and Philipp, A.: Circulation types 
and extreme precipitation days in the Iberian Peninsula in the transition seasons: Spatial links and temporal changes, Atmos. Res., 138, 41-58, 2014.

Fiori, E., Comellas, A., Molini, L., Rebora, N., Siccardi, F., Gochis, D.J., Tanelli, S., and Parodi, A.: Analysis and hindcast simulations of an extreme rainfall event in the Mediterranean area: The Genoa 2011 case, Atmos. Res. 138, 13-29, 2014.

Flocas, H. A., Simmonds, I., Kouroutzoglou, J., Keay, K., Hatzaki, M., Bricolas, V., and Asimakopoulos, D.: On cyclonic tracks over the Eastern Mediterranean, J. Climate, 23, 5243-5257, 2010.

Fröhlich, L., Knippertz, P., Fink, A. H., and Hohberger, E.: An objective climatology of Tropical Plumes, J. Clim., 26, 5044-5060, doi:10.1175/JCLI-D-12-00351.1, 2013.

Fuelberg, H. E. and Biggar, D. G.,: The preconvective environment of summer thunderstorms over the Florida Panhandle, Weather Forecast., 9, 316-326, 1994.

Funatsu, B. M., Claud, C., and Chaboureau, J.-P.: Two case studies of severe storms in the Mediterranean using AMSU, Adv. Geosci., 12, 19-26, 2007a, http://www.adv-geosci.net/12/19/2007/.

Funatsu, B. M., Claud, C., and Chaboureau, J.-P.: Potential of Advanced Microwave Sounding Unit to identify precipitating systems and associated upper-level features in the Mediterranean region: Case studies, J. Geophys. Res., 112, D17113, doi:10.1029/2006JD008297, 2007b.

Funatsu, B. M., Claud, C., and Chaboureau, J. P.: Comparison between the large- scale environments of moderate and intense precipitation systems in the Mediterranean region, Mon. Weather Rev., 137, 3933-3959, 2009.

Goldreich, Y.: The Climate of Israel: Observation, Research and Application. Springer: Israel, Kluwer Academic/Plenum Publishers: Netherlands, p. 298, 2003.

Gomez-Hernandez, M., Drumond, A., Gimeno, L., and GarciaHerrera, R.: Variability of moisture sources in the Mediterranean region during the period 1980-2000, Water Resour. Res., 49, 6781-6794, doi:10.1002/wrcr.20538, 2013.

Goodess, C. M. and Jones, P. D.: Links between circulation and changes in the characteristics of Iberian rainfall, Int J. Climatol., 22, 1593-1615, 2002.

Harats, N., Ziv, B., Yair, Y., Kotroni, V., and Dayan, U.: Lightning and rain dynamic indices as predictors for flash-floods events in the Mediterranean, Adv. Geosci., 23, 57-64, 2010, http://www.adv-geosci.net/23/57/2010/.

Haylock, M. R., Hofstra, N., Klein Tank, A. M. G., Klok, E. J., Jones, P. D., and New, M.: A European daily highresolution gridded dataset of surface temperature and precipitation for 1950-2006, J. Geophys. Res.-Atmos., 113, D20119, doi:10.1029/2008JD10201, 2008.

Hertig, E., Seubert, S., Paxian, A., Vogt, G., Paeth, H., and Jacobeit, J.: Statistical modelling of extreme precipitation indices for the Mediterranean area under future climate change, Int. J. Climatol., 34, 1132-1156, 2014.

HMSO: Weather in the Mediterranean I: General Meteorology. 2d Ed. Her Majesty's Stationery Office, 362 pp., 1962.

Homar, V. and Stensrud, D. J.: Sensitivities of an intense Mediterranean cyclone: Analysis and validation, Q. J. Roy. Meteor. Soc., 130, 2519-2540, 2004.

Horvath, K., Fita, L., Romero, R., Ivancan-Picek, B., and Stiperski, I.: Cyclogenesis in the lee of the Atlas Mountains: a factor separation numerical study, Adv. Geosci., 7, 327-331, doi:10.5194/adgeo-7-327-2006, 2006.

Hoskins, B. J. and Hodges, K. I.: New perspectives on the Northern Hemisphere winter storm tracks, J. Atmos. Sci., 59, 1041-1061, 2002.

Hurrell, J. W., Kushnir, Y., Ottersen, G., and Visbeck, M.: An Overview of the North Atlantic Oscillation, in The North Atlantic Oscillation: Climatic Significance and Environmental Impact, edited by: Hurrell, J. W., Kushnir, Y., Ottersen, G., and Visbeck, M., American Geophysical Union, Washington, D.C., Geophysical Monograph Series, Vol. 134, American Geophysical Union, 1-35, doi:10.1029/134GM01, 2003.

Jacobeit, J.: Variations of trough positions and precipitation patterns in the Mediterranean area, J. Climatol., 7, 453-476, 1987.

Jacovides, C. P. and Yonetani, T.: An evaluation of stability indices for thunderstorm prediction in Greater Cyprus, Weather Forecast., 5, 559-569, 1990.

Jansa, A., Genoves, A., and Garcia-Moya, J. A.: Western Mediterranean cyclones and heavy rain. Part 1: Numerical experiment concerning the Piedmont flood case, Meteorol. Appl. 7, 323-333, 2000.

Jansa, A., Genoves, A., Picornell, M. A., Campins, J., Riosalido, R., and Carretero, O.: Western Mediterranean cyclones and heavy rain, Part 2: Statistical approach, Meteorol. Appl., 8, 43-56, 2001.

Jansa, A., Alpert, P., Arbogast, P., Buzzi, A., Ivancan-Picek, B., Kotroni, V., Llasat, M. C., Ramis, C., Richard, E., Romero, R., and Speranza, A.: MEDEX: a general overview, Nat. Hazards Earth Syst. Sci., 14, 1965-1984, doi:10.5194/nhess-14-19652014, 2014.

Kahana, R., Ziv, B., Enzel, Y., and Dayan, U.: Synoptic climatology of major floods in the Negev Desert, Israel, Int J. Climatol., 22, 867-882, doi:10.1002/joc.766, 2002.

Kahana, R., Ziv, B., Dayan, U., and Enzel, Y.: Atmospheric predictors for major floods in the Negev Desert, Israel, Int J. Climatol., 24, 1137-1147, doi:10.1002/joc.1056, 2004.

Kelley, C., Ting, MF. Seager, R., and Kushnir, Y.: Mediterranean precipitation climatology, seasonal cycle, and trend as simulated by CMIP5, Geophys. Res. Lett., 39, L21703, doi:10.1029/2012GL053416, 2012.

Kenyon, J. and Hegerl, G. C.: Influence of modes of climate variability on global precipitation extremes, J. Climate, 23, 62486262, doi:10.1175/2010JCLI3617.1, 2010.

Knippertz, P. and Martin, J. E.: Tropical plumes and extreme precipitation in subtropical and tropical West Africa, Q. J. Roy. Meteor. Soc., 131, 2337-2365, 2005.

Knippertz, P.: Tropical-extratropical interactions related to upper level troughs at low latitudes, Dynam. Atmos. Oceans, 43, 3662, 2007.

Knippertz, P. and Wernli, H.: A Lagrangian climatology of tropical moisture exports to the Northern Hemispheric extratropics, J. Clim. 23, 987-1003, doi:10.1175/2009JCLI3333.1, 2010.

Korologou, M., Flocas, H., and Michalopoulou, H.: Developing an index for heavy convective rainfall forecasting over a Mediterranean coastal area, Nat. Hazards Earth Syst. Sci., 14, 22052214, 2014, http://www.nat-hazards-earth-syst-sci.net/14/2205/2014/.

Kotroni, V., Lagouvardos, K., Defer, E. Dietrich, S. Porcu, F. Medaglia, C. M., and Demirtas, M.: The Antalya 5 December 
2002 storm: Observations and model analysis, J. Appl. Meteor. Climatol., 45, 576-590, 2006.

Krichak, S. O. and Alpert, P.: Role of large-scale moist dynamics in November 1-5, 1994, hazardous Mediterranean weather, J. Geophys. Res.-Atmos., 103, 19453-19468, 1998.

Krichak, S. O. and Alpert, P.: Decadal trends in the east Atlanticwest Russia pattern and Mediterranean precipitation, Int. J. Climatol., 25, 183-192, 2005.

Krichak, S. O., Alpert, P., and Krishnamurti, T. N.: Red Sea trough/cyclone development - Numerical investigation, Meteorol. Atmos. Phys., 63, 153-170, 1997.

Krichak, S. O., Tsidulko, M., and Alpert, P.: Monthly synoptic patterns associated with wet/dry conditions in the Eastern Mediterranean, Theor. Appl. Climatol., 65, 215-229, 2000.

Krichak, S. O., Breitgand, J. S., and Feldstein, S. B.: A Conceptual Model for the Identification of Active Red Sea Trough Synoptic Events over the Southeastern Mediterranean, J. Appl. Meteor. Climatol., 51, 962-971, doi:10.1175/JAMC-D-11-0223.1, 2012.

Krichak, S. O., Breitgand, J., Gualdi, S., and Feldstein, S. B.: Teleconnection - extreme precipitation relationships over the Mediterranean region, Theor. Appl. Climatol., 117, 679-692, doi:10.1007/s00704-013-1036-4, 2014.

Krichak, S. O., Feldstein, S. B., Alpert, P., Gualdi, S., Scoccimarro, E., and Yano, J.-I.: Discussing the role of tropical and subtropical moisture sources in extreme precipitation events in the Mediterranean region from a climate change perspective, Nat. Hazards Earth Syst. Sci. Discuss., 3, 3983-4005, doi:10.5194/nhessd-33983-2015, 2015.

Kuhnel, I.: Tropical-extratropical cloudband climatology based on satellite data, Int J. Climatol., 9, 441-463, 1989.

Kutiel, H, and Paz S.: Sea level pressure departures in the Mediterranean and their relationship with monthly rainfall conditions in Israel, Theor. Appl. Climatol., 60, 93-109, 1998.

Lavers, D. A. and Villarini, G.: The nexus between atmospheric rivers and extreme precipitation across Europe, Geophys. Res. Lett., 40, 3259-3264, 2013.

Levy, I., Dayan, U., and Mahrer, I.: A 5-yr Study of the coastal recirculation and its effect on air pollutants over the East Mediterranean region, J. Geophys. Res., 113, D16121, doi:10.1029/07JD009529, 2008.

Lintynska, Z., Parfiniewicz, J., and Pinkovski, H.: The prediction of air mass thunderstorms and hails, WMO, 450, 128-130, 1976.

Lionello, P., Bhend, J., Buzzi, A., Della-Marta, P. M., Krichak, S., Jansà, A., Maheras, P., Sanna, A., Trigo, I. F., and Trigo, R.: Cyclones in the Mediterranean region: climatology and effects on the environment, edited by: Lionello, P., Malanotte-Rizzoli, P., and Boscolo, R., Mediterranean Climate Variability, Amsterdam: Elsevier, The Netherlands, 325-372, 2006.

Lionello, P. (Ed.): The climate of the Mediterranean Region. From the past to the future. Elsevier Insights, Elsevier, Amsterdam, The Netherlands, ISBN: 978-0-12-398466-1, 502 pp., 2012.

Maddox, R. A.: Mesoscale convective complexes, B. Am. Meteorol. Soc., 61, 1374-1387, 1980.

Maheras, P., Flocas, H. A., Anagnostopoulou, C., and Patrikas, I.: On the vertical structure of composite surface cyclones in the Mediterranean region, Theor. Appl. Climatol. 71, 199-217, 2002

Mariotti, A., Struglia, M. V., Ning Zeng, and Lau, K. M.: The Hydrological Cycle in the Mediterranean Region and Implications for the Water Budget of the Mediterranean Sea, J. Climate, 15, 1674-1690, 2002a.

Mariotti, A., Zeng, N., and Lau, K. M.: Euro-Mediterranean rainfall and ENSO- a seasonally varying relationship, Geophys. Res. Lett., 29, 59-1-59-4, 2002 b.

Martinez, C., Campins, J., Jansá, A., and Genoves, A.: Heavy rain events in the Western Mediterranean: An atmospheric pattern classification, Adv. Sci. Res., 2, 61-64, 2008.

Marullo, S., Santoleri, R., and Malanotte-Rizolli, P.: The sea surface temperature field in the Eastern Mediterranean from advanced very high resolution radiometer data, Part I, Seasonal variability, J. Mar. Syst., 20, 63-81, 1999.

Massacand, A. C., Wernli, H., and Davies, H. C.: Heavy precipitation on the alpine southside: An upper-level precursor, Geophys. Res. Lett., 25, 1435-1438, 1998.

Melani, S., Pasi, F., Gozzini, B., and Ortolani, A.: A four year (2007-2010) analysis of long-lasting deep convective systems in the Mediterranean Basin, Atmos. Res., 123, 151-166, 2013.

Miglietta, M. M. and Rotunno, R.: Numerical simulations of lowCAPE flows over a mountain ridge, J. Atmos. Sci., 67, 23912401, 2010.

Miglietta, M. M., Laviola, S., Malvaldi, A., Conte, D., Levizzani, V., and Price, C.: Analysis of tropical-like cyclones over the Mediterranean Sea through a combined modeling and satellite approach, Geophys. Res. Lett., 40, 2400-2405, doi:10.1002/grl.50432, 2013.

Millan, M. M., Estrela, M. J., and Caselles, V.: Torrential precipitations on the Spanish east coast: The role of the Mediterranean sea-surface temperature, Atmos. Res., 36, 1-16, 1995.

Moberg, A., Jones, P. D., Lister, D., Walther, A., Brunet, M., Jacobeit, J., Alexander, L. V., Della-Marta, P. M., Luterbacher, J., Yiou, P., Chen, D. L., Tank, A. M. G. K. Saladie, O., Sigro, J., Aguilar, E., Alexandersson, H., Almarza, C., Auer, I., Barriendos, M., Begert, M., Bergstrom, H., Bohm, R., Butler, C. J., Caesar, J., Drebs, A., Founda, D., Gerstengarbe, F. W., Micela, G., Maugeri, M., Osterle, H., Pandzic, K., Petrakis, M., Srnec, L., Tolasz, R., Tuomenvirta, H., Werner, P. C., Linderholm, H., Philipp, A., Wanner, H., and Xoplaki, E.: Indices for daily temperature and precipitation extremes in Europe analyzed for the period 1901-2000, J. Geophy. Res.-Atmos., 111, D22106, doi:10.1029/2006JD007103, 2006.

Mortimer, E. B., Johnson, G. A., Noble, D. G., and Ward, J. D.: An improved limited area quantitative precipitation forecast for west Texas, Preprint Second Conference on Flash Floods (Atlanta) AMS, Boston, 141-148, 1980.

Moses, T., Kiladis, G. N., Diaz, H. F., and Barry, R. G.: Characteristics and frequency of reversals in mean sea level pressure in the North Atlantic sector and their relationship to long-term temperature trends, J. Climatol., 7, 13-30, 1987.

Neumann, C. G. and Nicholson, J. R.: Multivariate regression techniques applied to thunderstorm forecasting at the Kennedy Space Center, Preprints, Inter. Conf. Aerospace and Aeronautical Meteor. Washington, DC, Amer. Meteor. Soc., 6-13, 1972.

Nuissier, O., Ducrocq, V., Ricard, D., Lebeaupina, C., and Anquetin, S.: A numerical study of three catastrophic precipitating events over southern France. I: Numerical framework and synoptic ingredients, Q. J. Roy. Meteor. Soc., 134, 111-130, doi:10.1002/qj.200, 2008. 
Park, S.: Remote ENSO influence on Mediterranean sky conditions during late summer and autumn: Evidence for a slowly evolving atmospheric bridge, Q. J. Roy. Meteor. Soc., 130, 2409-2422, 2004.

Pastor, F., Estrela, M. J. Penarrocha, P., and Millan, M. M.: Torrential rains on the Spanish Mediterranean coast: Modelling the effect of the sea surface temperature, J. Appl. Meteorol., 40, 11801195, 2001.

Pastor, F., Valiente, J. A., and Estrela, M. J.: Sea surface temperature and torrential rains in the Valencia region: modelling the role of recharge areas, Nat. Hazards Earth Syst. Sci., 15, 1677-1693, doi:10.5194/nhess-15-1677-2015, 2015.

Pickup, N. M.: Consideration of the effect of the $500 \mathrm{hPa}$ cyclonicity on the success of some thunderstorm forecasting techniques, Meteor. Mag., 111, 87-97, 1982.

Pinto, J. G., Ulbrich, S. Parodi, A. Rudari, R. Boni, G., and Ulbrich, U.: Identification and ranking of extraordinary rainfall events over Northwest Italy: The role of Atlantic moisture, J. Geophys. Res. Atmos., 118, 2085-2097, doi:10.1002/jgrd.50179, 2013.

Pozo-Vazquez, D., Gamiz-Fortis, S. R., Tovar-Pescador, J., EstebanParra, M. J., and Castro-Deiz, Y.: El Niño-Southern Oscillation events and associated European winter precipitation anomalies. Int. J. Climatol., 25, 17-31, 2005.

Price, C., Stone, L., Huppert, A., Rajagopalan, B., and Alpert, P.: A possible link between El Nino and precipitation in Israel, Geophys. Res. Lett., 25, 3963-3966, doi:10.1029/1998GL900098, 1998.

Raible, C. C.: On the relation between extremes of midlatitude cyclones and the atmospheric circulation using ERA40, Geophys. Res. Lett., 34, L07703, doi:10.1029/2006GL029084, 2007.

Ramis, C., Llasat, M. C., Genovés, A., and Jansá, A.: The October 1987 floods in Catalonia: synoptic and mesoscale mechanisms, Meteorol. Appl., 1, 337-350, 1994.

Ramis, C., Romero, R., Homar, V., Alonso, S., and Alarcon, M.: Diagnosis and numerical simulation of a torrential precipitation event in Catalonia (Spain), Meteorol. Atmos. Phys., 69, 1-21, 1998.

Ramis, C., López, J. M., and Arús J.: Two cases of severe weather in Catalonia (Spain). A diagnostic study, Meteorol. Appl., 6, 11-27, 1999.

Ramis, C., Romero, R., and Homar, V.: The severe thunderstorm of 4 October 2007 in Mallorca: an observational study, Nat. Hazards Earth Syst. Sci., 9, 1237-1245, doi:10.5194/nhess-9-1237-2009, 2009.

Raveh-Rubin, S. and Wernli, H.: Large-scale wind and precipitation extremes in the Mediterranean - a climatological analysis for 1979-2012, Q. J. Roy. Meteor. Soc., 141, 2404-2417, doi:10.1002/qj.2531, 2015.

Reale, O., Feudale, L., and Turato, B.: Evaporative moisture sources during a sequence of floods in the Mediterranean region, Geophys. Res. Lett., 28, 2085-2088, 2001.

Reale, M. and Lionello, P.: Synoptic climatology of winter intense precipitation events along the Mediterranean coasts, Nat. Hazards Earth Syst. Sci., 13, 1707-1722, doi:10.5194/nhess-131707-2013, 2013.

Reap, R. M. and Foster, D. S.: Automated 12-36 h probability forecasts of thunderstorms and severe local storms, J. Appl. Meteor., 18, 1304-1315, 1979.
Rigo, T. and Llasat, M. C.: Analysis of mesoscale convective systems in Catalonia using meteorological radar for the period 1996-2000, Atmos. Res., 83, 458-472, doi:10.1016/j.atmosres.2005.10.016, 2007.

Rimbu, N., Treut, H. L., Janicot, S., Boroneant, C., and Laurent, C.: Decadal precipitation variability over Europe and its relation with surface atmospheric circulation and sea surface temperature, Q. J. Roy. Meteor. Soc., 127, 315-329, 2001.

Rodo, X., Baert, E., and Comin, F. A.: Variations in seasonal rainfall in southern Europe during present century: Relationships with the North Atlantic Oscillation and the El Niño-Southern Oscillation, Clim. Dyn., 13, 275-284, 1997.

Romero, R., Guijarro, J. A., Ramis, C., and Alonso, S.: A 30-year (1964-1993) daily rainfall data base for the Spanish Mediterranean regions: first exploratory study, Int J. Climatol., 18, 541560, 1998.

Romero, R., Ramis, C., and Guijarro, J.A: Daily rainfall patterns in the Spanish Mediterranean area: an objective classification, Int. J. Climatol., 19, 95-112, 1999a.

Romero, R., Sumner, G., Ramis, C., and Genoves, A.: A classification of the atmospheric circulation patterns producing significant daily rainfall in the Spanish Mediterranean area, Int. J. Climatol., 19, 765-785, 1999b.

Romero, R., Ramis, C., and Alonso, S.: Numerical simulation of an extreme rainfall event in Catalonia: role of orography and evaporation from the sea, Q. J. Roy. Meteor. Soc., 123, 537-559, 1997.

Ropelewski, C. F. and Halpert, M. S.: Global and regional scale precipitation patterns associated with the El Nino-Southern Oscillation, Mon. Weather Rev., 115, 2352-2362, 1987.

Rubin, S., Ziv, B., and Paldor, N.: Tropical plumes over Eastern North Africa as a source of rain in the Middle-East, Mon. Weather Rev., 135, 4135-4148, 2007.

Rudari, R., Entekhabi, D., and Roth, G.: Large-scale atmospheric patterns associated with mesoscale features leading to extreme precipitation events in Northwestern Italy, Adv. Water Resour., 28, 601-614, 2005.

Saaroni, H., Ziv, B., Bitan, A., and Alpert, P.: Easterly wind storms over Israel, Theor. Appl. Climatol., 59, 61-77, 1998.

Saaroni, H., Halfon, N., Ziv, B., Alpert, P., and Kutiel, H.: Links between the rainfall regime in Israel and location and intensity of Cyprus lows, Int. J. Climatol., 30: 1014-1025, doi:10.1002/joc.1912, 2010.

Scaife, A. A., Folland, C. K., Alexander, L. V., Moberg, A., and Knight, J. R.: European climate extremes and the North Atlantic Oscillation, J. Climate, 21, 72-83, doi:10.1175/2007JCLI1631.1, 2008.

Segal, M., Arritt, R. W., Clark, C., Rabin, R., and Brown, J.: Scaling evaluation of the effect of surface characteristics on potential for deep convection over uniform terrain, Mon Weather Rev., 123, 383-400, 1995.

Senesi, S., Bougeault, P., Cheze, J. L., Consentino, Ph., and Thepenier, R. M.: The Vaison-la-Romaine flash flood: mesoscale analysis and predictability issues, Weather Forecast., 11, 417-442, 1996.

Shaman, J. and Tziperman, E.: An atmospheric teleconnection linking ENSO and Southwestern European precipitation, J. Climate, 24, 124-139, 2011. 
Sodemann, H. and Zubler, E.: Seasonal and inter-annual variability of the moisture sources for Alpine precipitation during 19952002, Int. J. Climatol., 30, 947-961, 2010.

Sordo, C., Frias, M. D., Herrera, S., Cofino, A. S., and Gutierrez, J. M.: Interval-based statistical validation of operational seasonal forecast in Spain conditioned to El NiñoSouthern Oscillation events, J. Geophys. Res., 113, D17121, doi:10.1029/2007JD009536, 2008.

Speranza, A.: The formation of baric depressions near the Alps, Ann. Geoph., 28, 177-217, 1975.

Speranza, A., Buzzi, A., Trevisan, A., and Malguzzi, P.: A theory of deep cyclogenesis in the lee of the Alps Part I: Modifications of baroclinic instability by localized topography, J. Atmos. Sci., 42, 1521-1535, 1985.

Toreti, A., Xoplaki, E., Maraun, D., Kuglitsch, F. G., Wanner, H., and Luterbacher, J.: Characterisation of extreme winter precipitation in Mediterranean coastal sites and associated anomalous atmospheric circulation patterns, Nat. Hazards Earth Syst. Sci., 10, 1037-1050, doi:10.5194/nhess-10-1037-2010, 2010.

Toreti, A., Martius, O., and Giannakaki, P.: Potential vorticity anomalies as precursors of extreme precipitation events in the Mediterranean region, Geophys. Res. Abstr., Vol. 16, EGU201410087, 2014.

Törnros, T.: On the relationship between the Mediterranean Oscillation and winter precipitation in the Southern Levant, Atmos. Sci. Lett., 14287-14293, doi:10.1002/as12.450, 2013.

Trigo, I., Davies, T. D., and Bigg, G. R.: Objective Climatology of Cyclones in the Mediterranean Region, J. Climate, 12, 16851696, 1999.

Trigo, I. F., Davies, T. D., and Bigg, G. R.: Decline in Mediterranean rainfall caused by weakening of Mediterranean cyclone, Geophys. Res. Lett., 27, 2913-2916, 2000.

Tubi, A. and Dayan, U.: Tropical plumes over the Middle-East: Climatology and synoptic conditions, Atmos. Res., 145-146, 168$181,2014$.

Tuduri, E. and Ramis, C.: The environments of significant convective events in the Western Mediterranean, Weather Forecast., 12, 294-306, 1997.

Turato, B., Reale, O., and Siccardi, F.: Water vapor sources of the October 2000 Piedmont flood, J. Hydrometeorol., 5, 693-712, 2004.

Ulbrich, U., Lionello, P., Belušić, D., Jacobeit, J., Knippertz, P., Kuglitsch, F. G., Leckebusch, G. C., Luterbacher, J., Maugeri, M., Maheras, P., Nissen, K. M., Pavan, V., Pinto, J. G., Saaroni, H., Seubert, S., Toreti, A., Xoplaki, E., and Ziv, B.: Climate of the Mediterranean: Synoptic Patterns, Temperature, Precipitation, Winds, and Their Extremes, edited by: Lionello P., The Climate of the Mediterranean Region, From the Past to the Future, Amsterdam: Elsevier The Netherlands, 301-346, ISBN: 9780124160422, 2012.
Ventura, F., Rossi Pisa, P., and Ardizzoni, E.: Temperature and precipitation trends in Bologna (Italy) from 1952 to 1999, Atmos. Res., 203-214, 2002.

Vicente-Serrano, S. M.: El Nino and La Nina influence on droughts at different timescales in the Iberian peninsula, Water Resour. Res., 41, W12415, doi:10.1029/2004WR003908, 2005.

Weckwerth, T. M., Bennett, L. J., Miller, L. J., Baelen, J. V., Di Girolamo, P., Blyth, A. M., and Hertneky, T. J.: An Observational and Modeling Study of the Processes Leading to Deep, Moist Convection in Complex Terrain, Mon. Weather Rev., 142, 26872708, 2014.

Winschall, A., Sodemann, H., Pfahl, S., and Wernli, H.: How important is intensified evaporation for Mediterranean precipitation extremes?, J. Geophys. Res.-Atmos., 119, 5240-5256, 2014.

Xoplaki, E., Gonzalez-Rouco, J. F., and Luterbacher, J.: Wet season Mediterranean precipitation variability: Influence of large-scale dynamics and trends, Clim. Dyn., 23, 63-78, 2004.

Xoplaki, E., Trigo, R. M., García-Herrera, R., Barriopedro, D., D’Andrea, F., Fischer, E. M., Gimeno, L., Gouveia, C., Hernández, E., Kuglitsch, F. G., Mariotti, A., Nieto, R., Pinto, J. G., Pozo-Vázquez, D., Saaroni, H., Toreti, A., Trigo, I. F., VicenteSerrano, S. M., Yiou, P., and Ziv, B.: Large-scale atmospheric circulation driving extreme climate events in the Mediterranean and its related impacts, The Climate of the Mediterranean Region, 347-417, 2012.

Yiou, P. and Nogaj, M.: Extreme climatic events and weather regimes over the North Atlantic: When and where?, Geophys. Res. Lett., 31, L07202, doi:10.1029/2003GL019119, 2004.

Zangvil, A. and Isakson, A.: Structure of the water vapor field associated with an early spring rainstorm over the Eastern Mediterranean, Israel J. Earth Sci., 44, 159-168, 1995.

Ziv, B.: A subtropical rainstorm associated with a tropical plume over Africa and the Middle-East, Theor. Appl. Climatol., 69, 91102, 2001.

Ziv, B., Dayan, U., and Sharon, D.: A mid-winter, tropical extreme flood-producing storm in southern Israel: Synoptic scale analysis, Meteorol. Atmos. Phys., 88, 53-63, doi:10.1007/s00703003-0054-7, 2004.

Ziv, B., Dayan, U., Kushnir, Y., Roth, C., and Enzel, Y.: Regional and global atmospheric patterns governing rainfall in the southern Levant, Int. J. Climatol., 26, 55-73, 2006.

Zorita, E., Kharin, V., and von Storch, H.: The atmospheric circulation and sea surface temperature in the North Atlantic area in winter: their interaction and relevance for Iberian precipitation, J. Climate, 5, 1097-1108, 1992. 